\title{
Broader-based and Sectoral Bargaining Proposals in Collective Bargaining Law Reform: A Historical Review
}

Sara Slinn

Osgoode Hall Law School of York University, sslinn@osgoode.yorku.ca

Follow this and additional works at: https://digitalcommons.osgoode.yorku.ca/all_papers

Part of the Labor and Employment Law Commons

\section{Repository Citation}

Slinn, Sara, "Broader-based and Sectoral Bargaining Proposals in Collective Bargaining Law Reform: A Historical Review" (2020). All Papers. 324.

https://digitalcommons.osgoode.yorku.ca/all_papers/324 


\title{
BRoAder-BASED \& SECTORAL BARgAining IN Collective BARgaining LAW REFORM:
}

\author{
A Historical ReView
}

Sara J. Slinn *

Forthcoming in (2020) Labour / Le Travail, Vol. 85

\begin{abstract}
Compelling evidence exists that centralized bargaining structures, including broaderbased and sectoral bargaining (BBB), offer significant benefits to workers. This article explores why the labour movement, despite the potential advantages offered by $B B B$, has not collectively pursued $B B B$ reforms. After briefly describing the concept of $B B B$, the author traces the history of $B B B$ as an issue in each of the labour law reform exercises across jurisdictions in English Canada between the late I980s and early 20I9, examining the context in which these issues arose, identifying key BBB proposals, and challenges to these proposals. It concludes with an analysis of the failure of efforts to incorporate BBB proposals into labour legislation, and an assessment of the key challenges to adopting significant $B B B$ reforms in the future.

Departing from earlier research, the article identifies different explanations of the labour movement's lack of support for BBB. First, while employers have opposed BBB, this not been a prominent feature in recent reforms. Second, it finds some unions' lack of support for BBB is no longer due to lack of awareness and understanding of the concept, but arises from three sources: concerns about preserving existing representation rights; resistance to the prospect of mandatory councils of unions; and, anticipation of jurisdictional conflicts. An additional contributing factor appears to be the consensus approach taken by some peak labour organizations in deciding which labour law reform issues to promote. Finally, given the highly politicized nature of labour law reform, and, therefore, the political cost of innovative and untried changes, it is not surprising that governments opted to forgo such a contentious route, despite the socio-economic benefits it may produce, particularly for workers.
\end{abstract}

\section{Introduction}

Compelling evidence exists that centralized bargaining structures, including broader-based and sectoral bargaining (BBB), as well as bargaining at the national level, offer significant benefits to workers, including higher levels of collective agreement coverage, better labour standards and labour market integration for vulnerable workers, reduced unemployment, higher employment,

\footnotetext{
* Associate Professor and Associate Dean (Research and Institutional Relations), Osgoode Hall Law School, York University.
} 
and reduced wage inequality. ${ }^{1}$ However, BBB had not been the subject of significant post-war labour law reform discussion in Canada, outside of Québec until the I990s. Coinciding with economic and political changes posing critical challenges to the labour movement, this decade saw a wave of interest in introducing BBB arise across several jurisdictions. Originating in Ontario in the late I980s, it spread to British Columbia as a key part of labour law reform discussions in the early and late I990s and became a minor issue in the federal labour law reform review process later that decade. ${ }^{2}$ None of these reviews resulted in substantial BBB amendments to labour legislation.

Since then, and despite the continuing decline of private sector unions, until the Changing Workplaces Review (CWR) of Ontario's Labour Relations Act (OLRA) and Employment Standards Act (ESA) commenced in 2015, BBB had not re-emerged as an important reform issue. ${ }^{3}$ BBB gained significant attention in the CWR process, and was also an issue in the subsequent labour law reform processes undertaken in Alberta and British Columbia. However, in none of these instances were BBB proposals or recommendations adopted.

Why, despite the clear benefits to labour of BBB and the dire state of private sector unionism in Canada, did the labour movement not collectively press for BBB reforms? This article explores this conundrum. It begins by briefly describing the concept of BBB and noting the distinct experience of private sector labour relations outside of Québec in this regard. It then traces the history of BBB as an issue in each of the labour law reform exercises across jurisdictions in English Canada which took place between the late 1980 s and early 2019, examining the context in which these issues arose, identifying key BBB proposals, and challenges to these proposals. It concludes with an analysis of the failure of efforts to incorporate BBB proposals into labour legislation, and an assessment of the key challenges to adopting significant BBB reforms in the future. ${ }^{4}$

${ }^{1}$ For summaries of these research findings see: ILO, "Trends in Collective Bargaining Coverage: Stability, Erosion or Decline?” INWORK Issue Brief No. 1. (Geneva: ILO, 2017) and OECD, OECD Employment Outlook 2018, (OECD Publishing: Paris, 2018), Chapter 3,

${ }^{2}$ Although amendments to broader-based bargaining structures were also an issue in Québec in the I990s, that debate is not addressed in this article as it arose primarily in the context of contemplated reform of an existing sectoral bargaining scheme, rather than introduction of a new BBB model.

${ }^{3}$ Ontario, Labour Relations Act, 1995, S.O. 1995, c I, Sch A; Ontario, Employment Standards Act, 2000, S.O. 2000, c 4I.

${ }^{4}$ This study employs review of primary and secondary documents and semi-structured interviews conducted between October 2016 and May 20I8. Interviewees include Cameron Dykstra, Director of Research, Alberta Federation of Labour, 26 April 20I8; David Fairey, labour economist and research associate of the Canadian Centre for Policy Alternatives, I5 December 20I6; Ken Georgetti, former President of the BC Federation of Labour, interview by author, I3 April 20I7; Stan Lanyon, mediator-arbitrator, interview by author, 7 November 2016; Vince Ready, arbitratormediator, interview by author, 22 June 20I7; Chris Schenk, former OFL Research Director, interview by author, I3 October 20I6; John Weir, former staff director and labour researcher, BC Federation of Labour, interview by author, I2 April 2017; Fred Wilson, retired Director of Strategic Planning, Unifor, interview by author, Io July 20I7; Anita Zaenker, Director of Organizing, BC Federation of Labour, interview by author, 24 May 20I8; two anonymous Union Representatives, 


\section{Broader-Based and Sectoral Bargaining}

Canadian labour legislation reflects the Wagner model, which is characterized by decentralized bargaining structures: highly fragmented bargaining units centred on bargaining between a union and a single-employer at the individual workplace level. Decentralization is, in turn, associated with reduced union bargaining power and lower rates of collective bargaining coverage, lower labour standards for vulnerable workers, higher unemployment, lower employment, weaker labour market integration of vulnerable workers, and greater wage inequality, compared to more centralized systems where bargaining occurs at sectoral, industrial or even national levels, as is common outside of North America. ${ }^{5}$ Moreover, in countries with enterprise level bargaining, collective bargaining rates and union density are not only low but declining, ${ }^{6}$ and where enterprise bargaining replaces more centralized arrangements, bargaining coverage rates fall substantially. ${ }^{7}$

In addition, decentralized, Wagner model systems relying on a statutory certification process for access to collective bargaining, are criticized as effectively precluding many workers - particularly precarious workers - from accessing statutory collective bargaining. ${ }^{8}$ In contrast, BBB systems commonly provide more liberal access to collective agreement coverage than certification-based models. Consequently, BBB systems may be accessible to workers for whom the certification process is an effective barrier to collective bargaining. ${ }^{9}$

Workers and unions are not the only parties who may benefit from BBB. Labour relations boards have expressed a preference for larger bargaining units, minimizing fragmentation and avoiding a proliferation of units, recognizing broader-based labour relations structures benefit employees, employers and contributing to more stable labour relations. ${ }^{10}$ Benefits to employees

interviewed by author 22 and 24 May 20I8; and, one anonymous Labour Researcher, interviewed by author, I2 April 2017.

${ }^{5}$ For summaries of these research findings see: ILO, “Trends in Collective Bargaining Coverage: Stability, Erosion or Decline?” INWORK Issue Brief No. 1. (Geneva: ILO, 2017) and OECD, OECD Employment Outlook 2018, (OECD Publishing: Paris, 2018), Chapter 3,

6 Jelle Visser, Wage Bargaining Institutions - from Crisis to Crisis, European Economy Economic Papers, No. 488 (Directorate General Economic and Financial Affairs (DG ECFIN), European Commission, 2013), 12.

${ }^{7}$ ILO, Trends in Collective Bargaining Coverage, 6-7.

${ }^{8}$ See discussion at C. Michael Mitchell and John C. Murray, The Changing Workplaces Review: An Agenda for Workplace Rights - Final Report (Toronto: Ministry of Labour, 20I7), 347 and Ontario, Ministry of Labour, Changing Workplaces Review - Special Advisors' Interim Report (Toronto: Ministry of Labour, 20I6), 113.

${ }^{9}$ Jonathan B. Eaton, “Labour law reform for the new workplace: Bill 40 and beyond,"dissertation, University of Toronto, I994, 323; Intercede, Toronto Organization for Domestic Workers' Rights (hereafter Intercede), Meeting the Needs of Vulnerable Workers: Proposals for Improved Employment Legislation and Access to Collective Bargaining for Domestic Workers and Industrial Homeworkers (Toronto: Intercede, I993), 40.

${ }^{10}$ See C. Michael Mitchell and John C. Murray, Final Report, 347; North of Superior Healthcare Group v Service Employees’ Union Local 1 Canada, (2016) CanLII 55190 (ON LRB); SEIU, 
include: greater worker mobility; common employment conditions across an enterprise; reduced focus on wage competition; and, may reduce contracting out of work. Employers benefit from greater administrative efficiency, and employer organization among smaller firms to counterbalance union power. Reduced conflict resulting from bargaining above the workplace level and opportunities for ongoing dialogue, and establishment of uniform conditions, may lead to more stable labour relations. ${ }^{11}$

Rather than being a foreign concept, broader-based and sectoral representation and bargaining are long-standing features of collective bargaining regulation in this country, integrated within Wagner model systems. Broader-based and sectoral bargaining is a substantial feature of public sector labour relations in this country, particularly in British Columbia and Québec, which have long-established, highly centralized public sector bargaining structures, including negotiations occurring at the province-wide level. In contrast, BBB arrangements are uncommon in the private sector, arrived at either through statutory centralized bargaining or voluntary pattern bargaining, although labour legislation regulating Canada's private sector has incorporated forms of BBB in varying degrees for decades. ${ }^{12}$ Both historical and contemporary non-Wagner model, broader-based bargaining, statutory regimes have operated alongside Wagner Model systems in the private sector. These include the industry-specific construction collective bargaining regimes established in most jurisdictions, provincial Industrial Standards Acts, Status of the Artist Acts, and Québec's “Decrees” system. ${ }^{13}$ Together, these suggests that broader-based representation and bargaining is an ingrained element of collective bargaining regulation in this country.

The most prominent example of such a contemporaneous system is Québec's Decrees system, allowing for "decree” extensions of specified collective agreement terms to apply to employers and workers in a designated geographic and industrial sector, although they were not parties to the original collective agreement, and regardless of union status. Established in 1934 to combat unfair competition in wages and working conditions, the Decrees system pre-existed the province's 1944 Wagner model Labour Code, and the two systems continue to offer separate

Local 204 v Humber/Northwestern/York-Finch Hospital, 1997 CanLII 15494 (ON LRB); Island Medical Laboratories Ltd., (1993), 19 CLRBR (2d) 161.

11 SEIU, Local 204 v Humber/Northwestern/York-Finch Hospital, 1997 CanLII 15494 (ON LRB), paras. 32, 33; Labour Law Casebook Group. 2018. Labour \& employment law: cases, materials and commentary. $9^{\text {th }}$ ed. Toronto: Irwin Law, 525.

12 See for e.g. multi-employer bargaining structures available under BC collective bargaining legislation, which was narrowed in the I990s (British Columbia, Labour Relations Code, S.B.C. I993, c. 82; British Columbia, Labour Relations Code, S.B.C. I992, c. 82).

13 Regarding development of the construction regime see Harry W. Arthurs and John Crispo, "Countervailing Power in the Construction Industry: Accreditation of Contractor Associations," in Construction Labour Relations, eds. H. C. Goldberg and J.H.G. Crispo (Canadian Construction Association, 1968), 376-415; see for e.g. Ontario, The Industrial Standards Act, 1935, SO 1935, c 28; Québec, An Act Respecting the Professional Status and Conditions of Engagement of Performing, Recording and Film Artists, C.Q.L.R. c. S-32.1; Québec, An Act Respecting Collective Agreement Decrees, C.Q.L.R. c. D-2. 
routes to collective representation and bargaining for workers. ${ }^{14}$ Although the system has declined in recent decades, it remains active. In this regard, Québec is exceptional and, therefore, this article focuses on jurisdictions outside of Québec, which lack a comprehensive, statutory BBB regime applicable to the private sector.

Although BBB is an established element of labour relations systems in this country, this is not to say that it is easily reconciled with how enterprises prefer to organize their operations, labour relations, or workers. Employers still tend to oppose sectoral bargaining because it facilitates unionization, can lead to imposition of master agreements where no collective agreement would otherwise likely have been achieved, and is likely to reduce the availability of wage-based competition which smaller enterprises, in particular, may favour.

\section{Labour Law Reform in the 1990s}

Emergence of BBB proposals in I990s labour law reform shared some common contextual features among jurisdictions. This period was marked by significant difficulties for labour, including negative public policy changes, widespread downsizing, growing use of lean production strategies, increasingly hostile employer attitudes towards unions, aggressively concessionary bargaining, and growing servicing demands on unions resulting from employer reorganizing of work systems. These developments drew on unions' resources and resulted in less attention and resources being devoted to union organizing and community action. ${ }^{15}$ At the same time, labour market changes in the organization of work were producing a structural shift towards, and relative growth in, smaller workplaces. ${ }^{16}$ Voluntary broader-based bargaining arrangements, such as pattern bargaining operating in the unionized meat-packing, western forest, and Ontario brewery industries, had also collapsed as employers withdrew from these sector-wide arrangements. ${ }^{17}$ These changes were accompanied by a shift away from high-wage, semi-skilled jobs to low-wage service sector employment, made more acute by a developing economic recession which widened disparities in conditions among different groups of workers, highlighting the limited relevance of the existing statutory labour system for a growing proportion of workers.

During this period some scholars, as well as some in the labour movement, recognized that the changing economic context urgently required unions to recalibrate their approaches to organizing and retaining members. ${ }^{18}$ Moreover the fundamental inability of the Wagner Model to

${ }^{14}$ Québec, Collective Labour Agreements Extension Act, S.Q. 1934, c. 56; Labour Relations Act, S.Q. 1944, c. 30.

15 Pradeep Kumar, "Diffusing Innovations and Articulating Labour's Vision," Studies in Political Economy 74 (2004): I49.

16 John O'Grady, "Beyond the Wagner Act, What Then?" in Daniel Drache, ed., Getting on Track: Social Democratic Strategies for Ontario (Montréal: McGill-Queen's University Press, I992), I60, I64-I65; Charlotte A. B. Yates, "Staying the Decline in Union Membership: Union Organizing in Ontario, I985-I999," Relations industrielles/Industrial Relations 55, no. 4 (Fall 2000).

17 See Anne Forrest, "The Rise and Fall of National Bargaining in the Canadian Meat-Packing Industry,” Relations industrielles/Industrial Relations 44, no. 2 (Spring I989): 393-408.

${ }^{18}$ Christopher Schenk, "Fifty Years after PC roo3: The Need for New Directions," in Cy Gonick, Paul Phillips, and Jesse Vorst, eds., Labour Gains, Labour Pains: 5o Years of PC I003, (Halifax: 
serve small workplaces well, and the crucial importance of this given the shift in employment towards smaller workplaces, had also become evident to many. ${ }^{19}$

Among the starkest warnings of the danger and futility to the labour movement of continuing to pursue traditional organizing was issued in the early I990s by labour economist and former Ontario Federation of Labour (OFL) Research Director, John O’Grady. Based on his assessment of the greater difficulty of organizing smaller workplaces under the Wagner Model and evidence of a structural shift towards, and relative growth in, smaller workplaces, O'Grady concluded that sectoral or regional bargaining structures would be necessary to effectively regulate the private sector labour market. ${ }^{20}$

Declining union density was also a feature of this period. Peak density of 37.9 per cent was reached in 1983-84 in Canada, and remained high throughout the decade. ${ }^{21}$ Pradeep Kumar and Gregor Murray identify the turning point for union density in Canada as the moment in the early I980s when labour force growth began outpacing union membership growth. ${ }^{22}$ While union density dropped substantially in the I990s, the total number of union members continued to grow into the mid-I990s, although at a slower pace than before. ${ }^{23}$ Canada unions appeared to be in a relatively secure position compared to unions in other countries, and particularly the United States, which had undergone significant losses in aggregate membership and density. ${ }^{24}$ Some

Fernwood, I995); Paul C. Weiler, Governing the Workplace: The Future of Labor and Employment Law (Cambridge, Mass.: Harvard University Press, 1990).

${ }^{19}$ O'Grady, "Beyond the Wagner Act, What Then?" I57-I58; Yates, "Staying the Decline in Union Membership: Union Organizing in Ontario, I985-1999."

${ }^{20}$ O’Grady, "Beyond the Wagner Act, What Then?" I57-I58, I60, I64-I65. Key changes in work organization included increasing part-time, casual and home-work, contracting out, and outsourcing. In contrast to O'Grady, Paul Weiler advocated adoption and adaptation of European works councils as a possible future for governing the private sector workplace. Weiler, Governing the Workplace: The Future of Labor and Employment Law, 283-295.

${ }^{21}$ W Craig Riddell, "Unionization in Canada and the United States: A Tale of Two Countries," in David Card and Richard B. Freeman, eds., Small Differences That Matter: Labor Markets and Income Maintenance in Canada and the United States (Chicago: University of Chicago Press, I993), IIo, table 4.I.

22 Pradeep Kumar and Gregor Murray, "Strategic Dilemma: The State of Union Renewal in Canada," in Peter Fairbrother and Charlotte Yates, eds., Trade Unions in Renewal: A Comparative Study, (New York: Continuum, 2003), 202-203.

${ }^{23}$ Kumar and Murray, "Strategic Dilemma: The State of Union Renewal in Canada”; Pradeep Kumar and Christopher Schenk, "Union Renewal and Organizational Change: A Review of the Literature," in Pradeep Kumar and Christopher Schenk, eds., Paths to Union Renewal: Canadian Experiences (Peterborough, Ont: Broadview Press, 2006a), 50-5I.

${ }^{24}$ International Labour Organization, World Labour Report: Industrial Relations, Democracy and Social Stability (Geneva: International Labour Office, I997). 
commentators noted that this "membership illusion" 25 fostered "a degree of complacency" within the Canadian labour movement. ${ }^{26}$ Scholars have also identified other internal factors, including labour's fragmented structure, inter-union competition, and dilemmas about the focus of organizing efforts as key impediments to union renewal in Canada. ${ }^{27}$

As a result, union renewal debates were more limited and slower to emerge in Canada than elsewhere. ${ }^{28}$ Discussion of union revitalization strategies was limited, and within central labour bodies such as the OFL and the BC Federation of Labour (BC Fed) such concerns were met with resistance from leaders and affiliates. ${ }^{29}$

A final important contextual factor was political. Several jurisdictions also underwent significant swings in government during this period, as relatively labour- and worker-friendly social democratic parties came to power with strong majorities after long periods of conservative governments. Election of the New Democratic Party (NDP) in September I990 in Ontario and the following September in BC, and election of the federal Liberal party in 1993, represented windows of opportunity for progressive labour law reform. However, the particular challenges faced by such reform differed substantially among jurisdictions.

\section{A. Ontario in the 1990s}

The first concrete indication of labour interest in BBB in Ontario arose in policy resolutions and statements from the OFL's 1988 and 1989 conventions. Key among these was the policy statement, The Unequal Bargain, which arose from a study of juridical extension systems commissioned by the OFL and authored by a researcher from Labour Canada. ${ }^{30}$ The Unequal Bargain set out a "Designated Sector" proposal for BBB under the OLRA, which was then adopted at the OFL's I989 annual convention. ${ }^{31}$ The OFL was pursuing statutory mandatory multi-employer bargaining

${ }^{25}$ Gregor Murray, “Union Myths, Enigmas, and Other Tales: Five Challenges for Union Renewal,” Studies in Political Economy 74 (2004): I57-I69.

${ }^{26}$ Kumar and Schenk, "Union Renewal and Organizational Change: A Review of the Literature," $5 \mathrm{I}$.

${ }^{27}$ Yates, "Missed Opportunities and Forgotten Futures: Why Union Renewal in Canada Has Stalled"; Kumar and Murray, "Strategic Dilemma: The State of Union Renewal in Canada"; Pradeep Kumar and Gregor Murray, "Canadian Union Strategies in the Context of Change" Labor Studies Journal 26, no. 4 (2002); Kumar and Schenk, "Union Renewal and Organizational Change: A Review of the Literature."

${ }^{28}$ Pradeep Kumar and Christopher Robert Schenk, "Introduction," in Pradeep Kumar and Christopher Robert Schenk, eds., Paths to Union Renewal: Canadian Experiences (Peterborough, Ont: Broadview Press, 2006), I5.

${ }^{29}$ John Weir, interview by author, I2 April 20I7; Labour Researcher, interview by author, I2 April 20I7; Vince Ready, interview by author, 22 June 20I7; Chris Schenk, interview by author, I3 October 20I6; Fred Wilson, interview by author, Io July 2017.

${ }^{30}$ Labour Researcher, interview.

${ }^{31}$ Ontario Federation of Labour (hereafter OFL), The Unequal Bargain, 33 ${ }^{\text {rd }}$ Annual OFL Convention (Toronto: OFL, I989), 8. The Designated Sector model proposed amending the OLRA 
as a solution to what it regarded as ineffective OLRA voluntary employer council provisions. Following its 1989 convention, the OFL sought to develop broader support for BBB and repeatedly urged the government to strike a task force on what it termed "sectoral or broader-based bargaining."32

However, support for BBB within the OFL itself was mixed including within the organization's leadership which did not appear to regard it as a priority issue. ${ }^{33}$ Several private sector unions, including the Steelworkers, the International Ladies' Garment Workers' Union, and the United Food and Commercial Workers were supportive. However, a labour researcher involved in these discussions recalled that the Canadian Auto Workers (CAW), a large private-sector union, was skeptical - if not hostile - to the idea. ${ }^{34}$ As a former OFL Research Director noted, the CAW's militant approach to bargaining and strikes would not be readily compatible with being bound to a arrangement that would likely require more conciliatory relations among government, management, and labour, and less resort to bargaining power in disputes. ${ }^{35}$

Some public sector unions, such as the Ontario Public Service Employees Union (OPSEU) did not regard statutory BBB as particularly useful given that they already engaged in relatively centralized bargaining, reflecting OPSEU's largely government worker membership. The Canadian Union of Public Employees (CUPE), among the largest public sector unions in the province, was strongly opposed to the concept of BBB. ${ }^{36}$ Its opposition arose in part from the importance CUPE places on its locals' independence and autonomy. CUPE regarded BBB as threatening such independence and local democracy and fostering bureaucracy. ${ }^{37}$

Even before the NDP came to power in Ontario in the fall of I990, the predecessor Liberal government and the Ministry of Labour had been contemplating broader-based, legislative responses to certain difficult workplace issues. These included employer responsibility and successor rights in contract services; extending the scope of administratively complex pay equity legislation to workers falling outside the existing legislation and to smaller workplaces; and, a credible challenge to exclusion from basic ESA protections of certain categories of workers such as domestics, nannies, and agricultural workers, as a denial of the Charter of Rights and Freedoms

to permit the labour relations board to declare a group of employers engaged in similar enterprises, with workplaces of 50 or fewer employees and within a specified region, to be a "designated sector". Councils of certified unions and councils of unionized employers would negotiate collective agreements. Agreements would apply fully only to unionized employers, but key economic terms would be extended to all employers in the designated sector.

${ }^{32}$ Chris Schenk, interview; OFL, "Submission by the Ontario Federation of Labour to the Ministry of Labour Regarding Proposed Reform to the Ontario Labour Relations Act" (Toronto: OFL, I992); OFL, "Submission by the Ontario Federation of Labour to the Standing Committee on Resources Development on Bill 40" (Toronto: OFL, I992).

${ }^{33}$ Chris Schenk, interview.

${ }^{34}$ Labour Researcher, interview.

${ }^{35}$ Chris Schenk, interview.

${ }^{36}$ Labour Researcher, interview.

${ }^{37}$ Labour Researcher, interview. 
section I5 guarantee of equality rights. Recognizing that these were difficult issues to resolve through legislation, the government and Ministry was considering whether a solution might lie in BBB. $^{38}$

Shortly after coming to power the NDP commenced what became a two-year process of comprehensive OLRA reform. It turned into a highly conflict-ridden exercise, marred by leaks of confidential reports and mutual distrust and acrimony between and among the government, the Ministry, labour, and business. The Labour Relations Act Reform Committee was appointed in March I99I by the Minister of Labour, Bob MacKenzie, and included arbitrator Kevin Burkett as Chair, union-side labour lawyer Elizabeth McIntyre as special advisor to the Committee, and three representatives from both labour and management. The Committee was given 30 days to consider specified issues relating to labour law reform, including the issue of "sectoral bargaining." The badly fractured Committee's final report, issued in April I99I, included separate labour and management side reports. The Chair “dissociated [him]self” from both documents, which the Chair subsequently described as “diametrically opposed.”39

The labour side report supported BBB, but without mentioning the OFL's Designated Sector proposal. Instead, it recommended appointing a task force to explore sectoral- or regionallevel bargaining as a means of extending representative structures to historically non-unionized workers. It identified what it labelled the " $20 / 20$ proposal," which contemplated a form of minority union representation on established works councils for workplaces with more than 20 employees, as the type of concept to be considered by this task force, though explicitly noting that it did not "believe that concept is necessarily suited to Ontario's needs." ${ }^{0}$ Meanwhile, the management side report dismissed sectoral bargaining as too complex and novel to address in the short period the Committee had available for its deliberations. ${ }^{41}$

John O’Grady, labour economist and former OFL Research Director, produced a discussion paper in May I99I outlining terms of reference, composition, timeline, and research issues for a provincial task force on broader-based bargaining and sectoral wage-setting. ${ }^{42}$ The OFL Research Director at the time, Chris Schenk, made suggestions for appointments to head the task force and to serve as research director, after the Ministry indicated that it couldn't find anyone willing to

${ }^{38}$ Unattributed, "A Sectoral Thrust to Labour-Management Relations: Background Paper for the Communications and Electrical Workers of Canada," (I992), II, I6.

39 Labour Relations Act Reform Committee (hereafter LRARC), Labour Relations Act Reform Committee Report (Toronto: Ontario Ministry of Labour, I99I); Kevin M. Burkett, "The Politicization of the Ontario Labour Relations Framework in the I990s" Canadian Labour \& Employment Law Journal 6 (1998): I70.

40 LRARC, Report of the Management Representatives (Toronto: Ontario Ministry of Labour, 1991), IO-II, I3-I4.

${ }^{41}$ LRARC, Report of the Management Representatives, 20.

42 John O'Grady, "Discussion Paper on the Terms of Reference, Composition, Timetable and Research Plan for a Provincial Task Force on Sectoral Wage-Setting and Broader-Based Bargaining," 6 May I99I. 
take on these roles. ${ }^{43}$ One labour researcher has suggested that many individuals who would have been regarded as candidates for such roles would likely have regarded BBB, and particularly an extension model such as the Designated Sector model, as "not a concept that you can graft onto our labour relations statute” and therefore would probably have been reluctant to participate. ${ }^{44}$

The Ministry's August I99I submission to Cabinet on OLRA reform options included proposing a task force on BBB and sectoral wage determination. ${ }^{45} \mathrm{~A}$ leak of, first, the labour-side report, and then the Cabinet submission, were met with strong opposition from business. This led the government to emphasize the public consultation process that would follow and to try to distance the subsequent bill from the options for reform presented to Cabinet. ${ }^{46}$ Neither subsequent Ministry submissions to Cabinet, nor the Ministry’s November i99I Discussion Paper, proposed a BBB task force and the Ministry indicated to the labour movement that Cabinet would not entertain the idea at that time. ${ }^{47}$

Nonetheless, the government continued to show some interest in BBB, and in October I992, the Minister announced that a task force would be created, although it never materialized. The product of this law reform effort, Bill 40, came into effect in January I993, but included no BBB provisions. ${ }^{48}$

Thereafter, the NDP government made clear that Bill 40 would be the extent of its labour law reform efforts. Some in the labour movement concluded that, after the government had pushed Bill 40 through against tremendous employer resistance, it would have been too politically difficult to strike a BBB task force. ${ }^{49}$ In short, it appears that at this time in Ontario, the concept of BBB

${ }^{43}$ Chris Schenk, interview.

${ }^{44}$ Labour Researcher, interview.

45 "Cabinet Submission Analysis and Policy Options, Reform of the Labour Relations Act: Policy Options and Analysis (Confidential Document Prepared for the Ontario Cabinet)" ed. Ontario Ministry of Labour (Toronto: Ministry of Labour, I99I), 74.

${ }^{46}$ Judy Fudge, "Little Victories and Big Defeats: The Rise and Fall of Collective Bargaining Rights for Domestic Workers in Ontario," in Abigail B Bakan and Daiva Stasiulis, eds., Not one of the family: Foreign domestic workers in Canada (Toronto: University of Toronto Press, I997), I32.

${ }^{47}$ Unattributed, "A Sectoral Thrust to Labour-Management Relations: Background Paper for the Communications and Electrical Workers of Canada," II, i6; Eaton, "Labour law reform for the new workplace: Bill 40 and beyond," 3I4.

48 Fudge, "Little Victories and Big Defeats," I32; Eaton, "Labour law reform for the new workplace: Bill 40 and beyond," 3I5; Ontario, Bill 40, An Act to amend certain Acts concerning Collective Bargaining and Employment, 2d sess., 35th Leg., I992. Continuing government interest in BBB also included contributing financial support for a May I992 conference, "Broadening the Bargaining Structures in the New Social Order: International Perspectives for Ontario,” held by the Centre for Research on Work and Society in cooperation with the OFL; commissioning studies on sectoral bargaining and its impact on low-wage workers, on the Québec Decrees system. Trade Union Research Bureau (hereafter TURB), "Broader Based Bargaining," (Vancouver: TURB, I992), 2; Eaton, "Labour law reform for the new workplace: Bill 40 and beyond," 3 I4.

${ }^{49}$ Chris Schenk, interview. 
and a task force to study options became casualties of politics and extreme business opposition to comprehensive labour law reform, rather than opposition to the merits of the idea itself.

Nonetheless, the OFL continued to be interested in BBB, and released The Big Picture, a comprehensive study of BBB in late $1993 .{ }^{50}$ According to the OFL Research Director at the time, Chris Schenk, this study did not attract much support or interest either within the OFL or among its affiliates, although it was widely circulated. He attributes this to corporatist interpretations of the study. The OFL did not intend it to promote corporatist reform, an approach which many unions would oppose. For instance, a corporatist approach would conflict with the militant character of some private sector unions' approaches to bargaining and strikes. Conversely, some public sector unions which already engaged in relatively centralized bargaining with government did not regard corporatist initiatives as a priority. ${ }^{51}$

\section{B. British Columbia’s Industrial Relations Act Review}

Following decades of conservative Social Credit governments in BC, Michael Harcourt led the NDP to a fall I99I election win. After many years of what labour regarded as aggressively antiunion Social Credit labour law changes, there was a general expectation that the new government would undertake union-friendly law reform.

The NDP government promptly commenced two significant labour law reform exercises. First, in February 1992 a Sub-committee of Special Advisors on the Industrial Relations Act was appointed, composed of union-side labour lawyer John Baigent, employer-side labour lawyer Tom Roper, and mediator and arbitrator Vince Ready (the "Sub-committee"). It was tasked with reviewing the province's general labour relations legislation. ${ }^{52}$ In March, the Commission of Inquiry into the Public Service and Public Sector was established to review labour relations and human resources practices and structures in the public sector and public service, under Commissioner Judi Korbin (the “Korbin Commission”).

The Sub-committee's final report, issued in September 1992, proposed a form of BBB that would apply to small workplaces in historically non-unionized sectors. This proposal has become known as the "Baigent-Ready Model," after the two Special Advisors who developed and proposed this recommendation in the Sub-committee's final report. The third Special Advisor, the employerside representative, opposed this recommendation. ${ }^{53}$

The Baigent-Ready Model was among the few Sub-committee recommendations that were not incorporated into the new Labour Relations Code introduced later that year. ${ }^{54}$ In contrast, the

${ }^{50}$ Geoffrey H. Brennan, "The Big Picture: A Review of Canadian and International Experience," (Toronto: Ontario Federation of Labour, I993).

${ }^{51}$ Chris Schenk, interview.

52 British Columbia, Industrial Relations Act, R.S.B.C. I979, c. 2 I2.

53 British Columbia, Ministry of Labour and Consumer Services, "Recommendations for Labour Law Reform: A Report to the Honourable Moe Sihota, Minister of Labour / Submitted by the SubCommittee of Special Advisers, John Baigent, Vince Ready, Tom Roper" (Victoria: Ministry of Labour and Consumer Services, I992).

${ }^{54}$ British Columbia, Labour Relations Code, 1992. 
government did adopt the Korbin Commission's June 1993 final report recommendations to reorganize public sector bargaining in the province into a highly centralized, broader-based structure, incorporating multi-party, two-tiered bargaining. ${ }^{55}$

Unlike Ontario's earlier labour law reform exercise, in this case the Special Advisors, rather than the labour movement, were primarily responsible for driving interest in BBB reforms. At the time of the Sub-committee's review, the labour movement in BC had not yet established a policy on $\mathrm{BBB}$ and there had been little discussion of the issue by or among unions. Moreover, the labour movement had not yet started to focus its efforts on under- or un-organized sectors, instead continuing to concentrate on servicing existing members. ${ }^{56}$

In contrast, Baigent and Ready were acutely aware of the implications of the changing economy and the associated shift towards smaller workplaces for collective bargaining and unionization and recognized that the Wagner Model was ineffective for smaller workplaces. These concerns were the genesis of the Baigent-Ready Model. ${ }^{57}$ Their efforts included meeting with representatives of the labour movement in $\mathrm{BC}$ and other provinces, and seeking input on, and trying to ignite interest in, a new, broader-based, approach to organizing and collective representation in small workplaces and under-represented sectors. ${ }^{58}$ According to then-President of the BC Fed, Ken Georgetti, the Special Advisors “... made a very compelling case to us that we should have a look at this kind of a model ...." 59 At the same time, the President of the OFL was also encouraging the BC Fed to look at the BBB issue. ${ }^{60}$

A small group of unions and unionists were actively interested in the issue and not only supported, but promoted, BBB options. These were primarily resource-based unions, such as the Steelworkers, the Canadian Paperworkers Union, and the Telecommunication Workers Union, which had histories of broader-based bargaining, either through their practice of organizing across occupations, industries, and establishments in resource towns, or through industry-wide bargaining councils. ${ }^{61}$ These unions were aware of the advantages of less fragmented bargaining structures for labour, and had experienced the negative consequences of the breakdown of broader-based bargaining, and the shift towards enterprise level bargaining that had been occurring in resource sectors since the I980s. Consequently, they were interested in revitalizing BBB structures in their industries. $^{62}$

55 British Columbia, Commission of the Inquiry into the Public Service and the Public Sector, Final Report (Victoria: Crown Publications, I993); British Columbia, Public Sector Employers Act, R.S.B.C. 1996 , c. 384 .

${ }^{56}$ Fred Wilson, interview.

${ }^{57}$ Vince Ready, interview.

${ }^{58}$ Vince Ready, interview; John Weir, interview; Ken Georgetti, interview.

${ }^{59}$ Ken Georgetti, interview.

${ }^{60}$ Ken Georgetti, interview.

${ }^{61}$ Vince Ready, interview; John Weir, interview. Diane MacDonald, “Sectoral Certification: A Case Study of British Columbia,” Canadian Labour and Employment Law Journal 5 (1997): 278.

62 John Weir, interview. 
Some public sector unions also pressed for BBB before both the Sub-committee and the Korbin Commission. The leadership of the BC Nurses' Union (BCNU) was among the first in the province's labour movement to support and explore the concept of BBB. Three health care unions, the BCNU, the Health Sciences Association (HSA) and Health Employees' Union (HEU) made a joint submission to the Sub-committee to advocate for BBB reforms. ${ }^{63}$ At the time, these unions regarded sectoral bargaining as an organizing and growth strategy, and a means of slowing the expansion of precarious work in health care, particularly in the home care sector where work was rapidly being de-professionalized into contracted service work. ${ }^{64}$

Among the strongest advocates for BBB was John Shields, long-time president of the BC Government Employees' Union (BCGEU). ${ }^{65}$ This union represented many workers in public and private health care facilities, including numerous care homes. Under Shields' leadership, the BCGEU had focused on organizing new members, and on creating an extra-statutory system of $\mathrm{BBB}$ in the sector, composed of voluntary bargaining councils and multi-employer bargaining structures with sector-wide master agreements. ${ }^{66}$ The BCGEU, in particular, had been pressing the NDP to strike a commission to consider introducing a statutory BBB framework for the public sector in advance of the Korbin Report. ${ }^{67}$

Overall, while there was interest and support for BBB among some unions in specific sectors and industries, it was limited. As one labour researcher recalls, "there was almost zero pick up in the labour movement itself on those issues." 68 According to Vince Ready, the Special Advisors' efforts failed to elicit any real insights about broader-based options from the labour community, and the Sub-committee heard "virtually nothing" on the matter from those appearing at public consultation hearings. ${ }^{69}$ Moreover, few written submissions to the Sub-committee addressed $\mathrm{BBB}$, with none offering specific proposals. ${ }^{70}$ According to a former labour researcher

63 The Health Care Unions of British Columbia (HCUBC), "Submission to the Special Committee of Advisors on the Industrial Relations Act” (Burnaby, BC: HCUBC, I992). Notably, the BCNU was not affiliated with the BC Fed or the Canadian Labour Congress at the time.

${ }^{64}$ Fred Wilson, interview.

${ }^{65}$ Vince Ready, interview.

${ }^{66}$ Ken Georgetti, interview.

67 John Shields, interview by Ken Novakowski and Bailey Garden, November 23, 20I6, in “Summary, BC Labour Heritage Centre Oral History Project,” (Burnaby, BC: BCLHC 8).

${ }^{68}$ Fred Wilson, interview.

${ }^{69}$ Vince Ready, interview.

${ }^{70}$ Diane MacDonald, "The New Deal Model of Collective Bargaining and the Secondary Labour Market" (Boston: Northeastern University, I998), 259; TURB, "Broader Based Bargaining," 2; British Columbia, Ministry of Labour and Consumer Services, "Recommendations for Labour Law Reform,” Appendix 3, 35. Also see Diane MacDonald, “Sectoral Certification: A Case Study of British Columbia," 278.

Notably the Vancouver and District Labour Council (VDLC) submitted a special memorandum responding to an informal request by the Special Advisors for a supplementary submission on whether barriers to collective bargaining for service and small workplace employees could be 
involved at the time, the Special Advisors were frustrated with labour's inability to "get [its] act together about what it wanted."71

As a result, the Baigent-Ready Model was largely the product of the Special Advisors' own deliberations, ${ }^{72}$ and "not really any sort of architecture from the labour movement" 73 or academics. ${ }^{74}$ Labour researcher John Weir describes the resulting proposal as something of a compromise, explaining: "I think they were trying to find something that they thought would be politically acceptable to - or might have some viability in terms of - the employer-side.”75

Nonetheless, the employer-side Sub-committee representative, Roper, remained opposed to the Baigent-Ready Model. He contended that, if adopted, the proposal would favour labour, and therefore would be outside the Sub-committee's mandate of proposing "fair and balanced" reform, and noted that few union submissions proposed BBB. ${ }^{76}$ He criticized the Baigent-Ready Model as contrary to the notion, accepted elsewhere in the Sub-committee's recommendations, that collective bargaining is the best foundation for a bargaining relationship. Instead, this proposal would allow employees to vote to unilaterally impose a standard contract on an employer, one that may not be suited to that workplace or employer, and one that an employer may not be willing to accept. Moreover, Roper regarded the Model as "investment negative” and likely to create a cartel problem among small workplaces. ${ }^{77}$ A labour arbitrator contends that Roper's key objection was

addressed through alternative approaches such as multi-employer or sectoral certification. The VDLC recommended striking a task force to consider whether a modified form of juridical extension would be effective, and amending the Industrial Relations Act to provide for mandatory, multi-employer bargaining and certification of a union or council of unions, and consolidation of units certified to the same union where the resulting unit would not be clearly inappropriate for bargaining. VDLC, "Memorandum to Special Committee of Advisors on B.C. Labour Law Reform," (Vancouver: VDLC, I992), I-2, 4; "Unfinished Business: Labour Law for British Columbia Workers," (Vancouver: VDLC, I997), I4; Diane MacDonald, "Sectoral Certification: A Case Study of British Columbia," 278.

A joint submission of three health care unions, BCNU, HEU and HSA, called for BBB legislation to operate in parallel with the general collective bargaining legislation, which would incorporate all public service employers into sectoral bargaining structures. See HCUBC, "Submission to the Special Committee of Advisors on the Industrial Relations Act.”.

${ }^{71}$ John Weir, interview.

72 John Weir, interview; Ken Georgetti, interview; Vince Ready, interview.

73 John Weir, interview.

${ }^{74}$ Fred Wilson, interview.

75 John Weir, interview.

${ }^{76}$ Ministry of Labour and Consumer Services, "Recommendations for Labour Law Reform," Appendix 3, 35.

77 Ministry of Labour and Consumer Services, "Recommendations for Labour Law Reform," Appendix 3, 35. For counterarguments to Roper's objections, see John Baigent, "What Is Sectoral 
accurate: it would impose master agreements as first collective agreements. ${ }^{78}$

By including the Baigent-Ready Model in their recommendations in the Sub-committee's final report, Baigent and Ready had hoped to spark a discussion on the issue, which had been lacking in the submissions and labour law reform process to that point. ${ }^{79}$ However, while the recommendation ignited employer opposition, labour continued to show little support for the proposal. ${ }^{80}$

In a comprehensive case study, Diane MacDonald describes employer opposition to the Baigent-Ready Model as "vigorous” and “often ideological," with objectors concentrated among small and medium sized businesses. ${ }^{81}$ Employers objected to the loss of "flexibility" that they regarded as a necessary consequence of negotiations occurring at a level beyond the individual enterprise. Smaller employers, in particular, were concerned about the prospect of becoming subject to a collective agreement imposed on them reflecting different business strategies, such as quality and productivity competition rather than price competition, which these businesses relied on. This imposition would result in an agreement that is not tailored to the specific workplace. Finally, some of the employer opposition was also attributed to employers recognizing that the Baigent-Ready Model would likely increase access to unionization. ${ }^{82}$

Overall, the labour movement's response was mixed, with labour leaders' reactions described as "very divided." 83 This division reflected widespread uncertainty about how the proposal would operate, ${ }^{84}$ and a lack of understanding of the issue and its significance ${ }^{85}$ The BC Fed President at the time described it as “ ... such a new concept that people couldn't get their heads wrapped around it.” In his view, the issue of BBB and this proposal in particular “... came [up] too quickly and [it] didn't give heads of unions enough time to really understand it and understand the implications of it." However, he also noted that the unfamiliarity and uncertainty

Bargaining?" Just Wages 3, no. 2 (1993), 7 and Diane MacDonald, "Sectoral Certification: A Case Study of British Columbia," 279-283.

78 Stan Lanyon, interview.

${ }^{79}$ Vince Ready, interview. For a summary of strengths and weaknesses of the Baigent-Ready Model, including a review of other commentators' assessments of the Model, see Sara Slinn, "Report to the Changing Workplaces Review" in Changing Workplaces Review Research Projects: Collective Bargaining, 84-88. http://cirhr.library.utoronto.ca/sites/cirhr.library.utoronto.ca/files/research-projects/Slinn-9-

Access $\% 20$ to $\% 20$ Collective $\% 20$ Bargaining.pdf

${ }^{80}$ Vince Ready, interview.

81 Diane MacDonald, “Sectoral Certification: A Case Study of British Columbia,” 274, 277.

82 John Baigent, "What is Sectoral Bargaining?" 7; Diane MacDonald, "Sectoral Certification: A Case Study of British Columbia,” 274, 275, 277-278.

83 John Weir, interview.

84 John Weir, interview.

${ }^{85}$ Ken Georgetti, interview. 
"wore off very quickly. After the fact, but we could never get it back on the table." 86 Others felt that some unions accustomed to the enterprise bargaining structure "didn't quite grasp the significance” of BBB. ${ }^{87}$

Many unions also had pragmatic concerns, seeing BBB and the Baigent-Ready Model as a threat to institutional union interests. They were concerned about inter-union competition, retaining bargaining rights, and the prospect of being forced into bargaining councils, and how inter-union disputes would be resolved under a BBB framework. ${ }^{88}$ In particular, some service sector unions were concerned that certain industrial unions with a strong emphasis on organizing would displace them from existing certified bargaining units. ${ }^{89}$ There was no consensus among unions about BBB, and some feared that sectoral certification would erode the place of individual unions in collective bargaining, and that employer-dominated unions would get the benefit of broader-based bargaining. ${ }^{90}$ Others were concerned that it represents a statutory solution to unions' difficulties achieving certifications and first contracts." 91 Finally, some in the labour movement viewed the Model as akin to the Québec decree system's extension system which, in their view, might "eliminate the need for people to join a union." 92

Even supporters of the Baigent-Ready Model had - and continue to have - reservations about its feasibility. Key concerns include how, in practical terms, to impose a collective agreement on a group of employers, particularly in the case of franchise operations; ${ }^{93}$ and, the challenge for unions to achieve a sectoral designation and initial certification, and to also negotiate a first agreement that would be suitable and sufficiently attractive for workers in additional workplaces to choose to be certified to join the initially certified unit. ${ }^{94}$

Nonetheless, by the time the government came to decide which recommendations to include in the new labour legislation, the BC Fed sought adoption of several contentious Subcommittee recommendations, including the Baigent-Ready Model of BBB. However, the Premier advised the BC Fed that the government was willing to adopt only one of the Sub-committee's non-consensus proposals: either the Baigent-Ready Model or the replacement worker provision, and the BC Fed could decide which one. ${ }^{95}$

${ }^{86}$ Ken Georgetti, interview.

${ }^{87}$ David Fairey, interview.

${ }^{88}$ Ken Georgetti, interview; Diane MacDonald, "Sectoral Certification: A Case Study of British Columbia," 276.

${ }^{89}$ Fred Wilson, interview.

90 John Weir, interview; Fred Wilson, interview.

${ }^{91}$ Stan Lanyon, interview.

92 John Weir, interview.

${ }^{93}$ Vince Ready, interview.

${ }^{94}$ Fred Wilson, interview.

95 Ken Georgetti, interview; Vince Ready, interview. Also see Diane MacDonald, "The New Deal Model of Collective Bargaining and the Secondary Labour Market," 278. 
In what has been characterized as "a historic choice," a "historic failure," and a decision made "for all the wrong reasons," the BC Fed gave up the opportunity to have the Baigent-Ready Model included in the new labour legislation. ${ }^{96}$ After lengthy debate among the BC Fed's executive, and then a vote, the replacement worker provision won by a single ballot. ${ }^{97}$

As then-President of the BC Fed, Ken Georgetti, explained, the replacement worker provision was really chosen for "the political optics of the labour movement," and partly influenced by the fact that the Ontario government had recently introduced anti-scab legislation, so the feeling was that BC labour "had to have anti-scab legislation." 98 This outcome likely reflected still-vivid memories many senior union officers had of violent and corrosive disputes on picket lines relating to replacement workers that had occurred in the I960s, I970s, and I980s. ${ }^{99}$ As more than one interviewee explained, for many long-time unionists at the BC Fed at the time, their reactions to the issue of replacement workers was almost "visceral." 100 Therefore, even though the BC Fed President may have recognized the importance of the Baigent-Ready Model proposal, it was not possible for his view to prevail, given the strength of feeling by many officers about "anti scab" protection. ${ }^{101}$ Since labour was clearly a "divided house" on the issue of BBB, ${ }^{102}$ in contrast with unanimity on the replacement worker proposal, there was little pressure on, or incentive for, the government to adopt the Baigent-Ready Model. ${ }^{103}$

Ultimately, the Baigent-Ready Model was not included in the subsequent extensive amendments to the labour legislation the government introduced in October 1992. ${ }^{104}$ The government's stated reason for not accepting the proposed Baigent-Ready Model was the uncertainty of its outcome and the restrictions it would impose on individual employers' ability to bargain individual collective agreements. ${ }^{105}$

The failure of the Baigent-Ready Model proposal has been attributed to strong opposition from the small business community, with these concerns conveyed in Roper's final report dissent.

On the issues of BBB, replacement worker protections, secondary boycott agreements, and picketing, one or more of the Special Advisors drafted dissents. See Ministry of Labour and Consumer Services, "Recommendations for Labour Law Reform," Appendices 2-5.

${ }^{96}$ Fred Wilson, interview.

${ }^{97}$ Ken Georgetti, interview; Vince Ready, interview.

${ }^{98}$ Ken Georgetti, interview.

${ }^{99}$ Stan Lanyon, interview.

${ }^{100}$ Stan Lanyon, interview; Fred Wilson, interview.

${ }^{101}$ Vince Ready, interview.

102 John Weir, interview; Ken Georgetti, interview.

${ }^{103}$ John Weir, interview; David Fairey, interview.

${ }^{104}$ British Columbia, Labour Relations Code.

${ }^{105}$ Minister's Statement, “An Introduction to Bill 84 - B.C.'S Proposed New Labour Legislation” (October 1992), I, cited in Diane MacDonald, "The New Deal Model of Collective Bargaining and the Secondary Labour Market," 279. 
In addition, lack of interest, weak support, and some opposition from labour; labour's prioritization of anti-scab provisions; and confusion and lack of awareness from all quarters about the Model and the BBB concept are also identified as causes. ${ }^{106}$ MacDonald concludes that this last reason, a general lack of understanding of the meaning or significance of $\mathrm{BBB}$, was among the key reasons this proposal was defeated. She found that some union officers were unaware that BBB was an issue before the Sub-committee, and there was significant confusion about the concept and how it might operate among those who were aware of it. Not only was labour ill-informed about BBB, but MacDonald found that some government officials were also confused about the Baigent-Ready Model. ${ }^{107}$ Nonetheless, the Baigent-Ready Model is still regarded as an innovative and powerful model. ${ }^{108}$

\section{Canada Labour Code Reform}

$\mathrm{BBB}$ arose as a minor issue in the mid-I990s review of collective bargaining under the Canada Labour Code, led by arbitrator and former Chair of the Alberta labour relations board Andrew Sims. ${ }^{109}$ Struck by Federal Minister of Labour Lucienne Robillard in June 1995, the "Sims Task Force” also included Rodrigue Blouin, an industrial relations professor, and Paula Knopf, an arbitrator and former OLRB Vice-Chair. ${ }^{110}$

The Sims Task Force Report, issued in January I996, addressed several aspects of "multiparty collective bargaining" in a chapter devoted to the topic. ${ }^{111}$ Overall, the Report demonstrated an equivocal attitude towards BBB stating that "There is nothing inherently wrong with broader based bargaining as long as unions and management remain free to revert to the simpler, single

106 MacDonald, "The New Deal Model of Collective Bargaining and the Secondary Labour Market," 275-278; John Baigent, "What Is Sectoral Bargaining?” 5; John Weir, interview; Vince Ready, interview; Ken Georgetti, interview.

${ }^{107}$ Diane MacDonald, “Sectoral Certification: A Case Study of British Columbia,” 276, 278. Some of this confusion may have arisen from, or been reflected in, the fact that the Baigent-Ready Model was variously termed "sectoral bargaining" and "multi-employer bargaining" at different points in the final report and its draft legislation.

${ }^{108}$ Fred Wilson, interview; C. Michael Mitchell and John C. Murray, Final Report, x.

109 Canada Labour Code, R.S.C., I985, c. L-2; Important differences exist between workplaces governed by federal, rather than provincial, labour relations legislation, and which are relevant to $\mathrm{BBB}$ considerations. Industries in the federal jurisdiction include a greater proportion of large employers and of industries with established histories of BBB. These industries have relatively high union density and collective agreement coverage, compared to those under provincial jurisdiction. (Canada, Human Resources and Skills Development Canada (hereafter HRSDC), A Profile of Federal Labour Jurisdiction Workplaces: Results from the 2008 Federal Jurisdiction Workplace Survey (Gatineau, QC: HRSDC, 20II), 7).

${ }^{110}$ Canada, Canada Labour Code, Part I, Review: Seeking a Balance, (Ottawa: Public Works and Government Services, I995).

111 This chapter specifically addressed: geographic certifications, multi-employer bargaining, broader-based bargaining, and sectoral bargaining. Canada, Canada Labour Code, Part I, Review: Seeking a Balance, Chapter 7. 
enterprise system if they wish.”112

Several union submissions to the Task Force advocated BBB for industries with low union density, intended to foster organizing in industries containing smaller, but similar workplaces. These "designated sector" proposals involved labour board designation of a sector identified by geographic scope and type of unit, following which all units certified within that sector would bargain together with an employers' group, with most proposals contemplating the same union representing all employees in the certified units in the sector. Additional units would be added to any existing sector-wide collective agreement upon certification, and these would participate in the next set of renewal negotiations. ${ }^{113}$ These proposals bore clear resemblances to the earlier OFL Designated Sector proposal and the Baigent-Ready Model.

Employers offered little response to these proposals, with objections centring on opposition to facilitating unionization, resistance to employers being required to bargain together, desire to protect the opportunity for wage and cost competition, and objection to newly certified employers being subject to a collective agreement they had not participated in negotiating. ${ }^{114}$

The Report dealt differently with multi-employer and single-employer sectoral bargaining. Noting that the issue of multi-employer sectoral bargaining "lacks any widespread consensus or even understanding," the Task Force did not recommend multi-employer sectoral bargaining. Instead, the Task Force recommended amending existing multi-employer bargaining provisions to ensure that employers could choose to engage in multi-employer bargaining, but could also withdraw and revert to individual bargaining in a subsequent bargaining round. ${ }^{115}$

Nonetheless, the Task Force concluded that "the idea [of broader multi-employer sectoral bargaining] raises a point that, in our view, merits further consideration” recognizing that, in industries with large employers with multiple worksites, the existing requirement of majority support across the region impedes organizing and could result in certification being imposed on individual worksites against those workers' wishes. In contrast, it also concluded that "we can see distinct advantages for both labour and management in having the Code allow a single employer but multi-establishment variant to the sectoral bargaining scheme.”116

Ultimately, the Task Force recommended adoption of a limited model of BBB, which it labeled "single-employer sectoral bargaining" recognizing that this model "offers efficiencies to both sides." 117 Under this model, the labour board could consolidate bargaining for existing certifications of the same employer. Subsequent certifications to that employer could later apply to be included in the consolidated bargaining. However, this was not included in the subsequent amendments to the Canada Labour Code.

The Sims Task Force was also directed to review BBB recommendations of an Industrial

\footnotetext{
112 Canada, Canada Labour Code, Part I, Review: Seeking a Balance, 79.

${ }^{113}$ Canada, Canada Labour Code, Part I, Review: Seeking a Balance, 95-96.

${ }^{114}$ Canada, Canada Labour Code, Part I, Review: Seeking a Balance, 96-97.

${ }^{115}$ Canada, Canada Labour Code, Part I, Review: Seeking a Balance, 97.

${ }^{116}$ Canada, Canada Labour Code, Part I, Review: Seeking a Balance, 97.

${ }^{117}$ Canada, Canada Labour Code, Part I, Review: Seeking a Balance, 97, 98.
} 
Inquiry Commission into Industrial Relations at West Coast Ports and, specifically, the Commission's recommendations regarding geographic certifications. ${ }^{118}$ The Federal Minister of Labour had appointed the Commission in May 1995 to make recommendations for more stable bargaining structures at West Coast ports, against a backdrop of frequent work stoppages. The Commission was underway at the time the Sims Task Force was appointed and its final report was issued in November 1995, two months before the final report of the Task Force. The Commission's Final Report included recommendations to broaden bargaining unit structures in grain longshoring and related port industries. ${ }^{119}$

The Sims Task Force disagreed with these recommendations, expressing skepticism that the potential benefit of BBB in reducing serial work stoppages outweighed the likelihood that negotiations would be impeded by issues relating to one part of broader units, and that this would encourage government intervention in the form of back to work legislation. Moreover, the Task Force regarded compulsory $\mathrm{BBB}$ as at odds with an increasingly deregulated and competitive transportation industry, concluding that "We find it difficult in such an environment to support what is, in effect, a more regulated labour relations regime in these industries."120

\section{British Columbia Labour Relations Code Reform}

After the 1992 Sub-committee review, the issue of BBB "went off the radar" in BC for several years. ${ }^{121}$ In the meantime Glen Clark, a former Steelworkers and Ironworkers union organizer, had become Premier following Premier Harcourt's February I996 resignation, and led the NDP to a bare majority government in the May 1996 election.

The following July, Minister of Labour John Cashore appointed a committee of special advisors (the LRC Committee) to review the BC Labour Relation Code (BC Code), with neutral co-chairs Vince Ready and Stan Lanyon, and two members: union-side lawyer Miriam Gropper and employer-side representative Jim Matkin. ${ }^{122}$

An important backdrop to this review was the government's failed attempt at construction and general labour relations reform earlier that year. The government had introduced Bill 44,

118 Canada Labour Code, R.S.C., I985, c. L-2; Canada, Canada Labour Code, Part I, Review: Seeking a Balance.

${ }^{119}$ Canada, Industrial Inquiry Commission into Industrial Relations at West Coast Ports, Report of the Industrial Inquiry Commission into Industrial Relations at West Coast Ports (Ottawa: Industrial Inquiry Commission into Industrial Relations at West Coast Ports, 1995) at pages 2I5217.

${ }^{120}$ Canada, Canada Labour Code, Part I, Review: Seeking a Balance, 93-94.

${ }^{121}$ Ken Georgetti, interview.

122 The LRC Committee was struck pursuant to the Section 3, continuing review of the Code, provision introduced into the BC Labour Relations Code on recommendation of the Subcommittee in 1992. 
without consultation, in June 1997. ${ }^{123}$ Faced with overwhelming business opposition, the government withdrew the Bill weeks later, and announced it would commence a review of both the construction and general labour relations legislation. The LRC Committee noted that both labour and management had indicated that the Bill 44 episode had increased the parties' polarization, and Lanyon later described it as "a shadow” hanging over the review. ${ }^{124}$

There was a general sense at the time that the government was unlikely to accept any LRC Committee recommendations to amend the $B C$ Code, and that its real interest was in the construction labour review - not the general BC Code review. ${ }^{125}$ There was also widespread skepticism within labour about the likelihood of obtaining dramatic change to the labour relations structure, and doubt about how effective change might be if it did occur, particularly as the government was not seen as willing to push hard for general labour reform at that time. ${ }^{126}$

Broader-based bargaining (referred to as "sectoral bargaining” throughout the review) became one of the primary issues before the LRC Committee and was addressed by a majority of the submissions received by the Committee. ${ }^{127}$

By the time of this review, the labour movement's growing awareness of the changing size, scope and organization of enterprises, particularly the growth of contracted out work and declining union density, made labour more receptive than before to new forms of representation, including $\mathrm{BBB}$, as a means of countering these changes. ${ }^{128}$ Yet, a significant lack of understanding of the concept and its implications persisted among unions. ${ }^{129}$ A discussion paper introduced to labour representatives at a Canada Labour Congress (CLC) winter school shortly before the review commenced was received with "a great deal of puzzlement," with one labour researcher describing it being as if the participants had been "presented ... with a foreign concept that was so different

${ }^{123}$ Stan Lanyon, "British Columbia Labor Policy Proposals," Perspectives on Work 2, 2 (I998): 29; British Columbia, Bill 44, Labour Statutes Amendment Act, I997, 2d sess., 36th Parliament, 1997 (first reading 25 June I997, withdrawn July I997).

124 British Columbia, Labour Relations Code Review Committee (hereafter LRCRC), Managing change in labour relations - the final report (Victoria, BC: Minister of Labour, I998), Part 2.B; Stan Lanyon, "British Columbia Labor Policy Proposals," 29. The LRC Committee also noted that this "context...resulted in Bill 44 defining the issues before us [and] the parties, to a large extent, focused their submissions on those issues.” LRCRC, Managing change in labour relations - the final report, Part I.B.3.

125 Ken Georgetti, interview.

126 John Weir, interview.

127 LRCRC, Managing change in labour relations - a discussion paper (Vancouver: LRCRC, I998), Section 3.2(a).

128 John Weir, interview.

${ }^{129}$ Fred Wilson, interview. 
from the world they were familiar with that they had trouble understanding it.”130

Before the LRC Committee, unions pressed for legislative solutions to structural barriers to collective representation: primarily $\mathrm{BBB}$ and broader successor rights provisions. Unions contended that for smaller workplaces, particularly in the service sector, BBB provisions were required to address barriers to access to union representation that exist in for smaller workplaces. ${ }^{131}$

Nonetheless, the labour movement clearly had not yet reached a consensus on, nor even fully come to grips with, the issue of BBB. Submissions proposed a variety of forms of BBB. Most unions advocated for adoption of the Baigent-Ready Model, although some unions contended that BBB should be extended to all employees, not only those in historically under-represented sectors. ${ }^{132}$ It appears the United Steelworkers of America, District 3, was the only union proposing a different, innovative approach to BBB. ${ }^{133}$ Overall, unions' interest in BBB tended to focus on contracted out services, such as janitorial work, rather than as a more broadly applicable model for restructuring collective representation and bargaining. ${ }^{134}$

Employers "categorically opposed” both BBB and expanded successorship provisions. As in I992, objections focused on the prospect of limits to competitive flexibility, imposition of "one size fits all” collective agreements, and employers' convictions that BBB would have a particularly strong negative effect on small and medium sized enterprises. ${ }^{135}$ Disagreement about what BBB entailed persisted within the employer community, as noted by the LRC Committee:

Some employers maintain that enterprise bargaining means one employer negotiating with one union, and that anything beyond this model is sectoral bargaining. They view multi-employer bargaining, coordinated bargaining, bargaining for master agreements, picking up the master agreement, and provincewide bargaining as unacceptable "sectoral models."136

130 Brian Shell and John O'Grady, "Taking Wages out of Competition: Models and Options for Sectoral Initiatives," Discussion paper presented to the BC Federation of Labour on behalf of United Steelworkers of America, I997; Labour Researcher, interview.

${ }^{131}$ LRCRC, Managing change in labour relations - a discussion paper, Section 2.2(b)(i)-(ii).

132 LRCRC, Managing change in labour relations - the final report, Part 2.C.3.

133 This proposal involved a tripartite committee determination and enforcement of minimum standards orders covering an array of matters, applicable as a floor for all employees, unionized or not, and with the Labour Board as final adjudicator if necessary. LRCRC, Managing change in labour relations - the final report, Part 2.C.3.

${ }^{134}$ Fred Wilson, interview.

135 LRCRC, Managing change in labour relations - a discussion paper, Section 2.2(b)(i)-(ii); LRCRC, Managing change in labour relations - the final report, Part 2.C.3.

${ }^{136}$ LRCRC, Managing change in labour relations - a discussion paper, Section 2.b.ii. 
These employer attitudes existed even though many of these bargaining structures had long been present in the province's labour relations without having been condemned as unacceptable forms of bargaining. ${ }^{137}$ The LRC Committee stated:

We believe that sectoral bargaining, along with other sectoral strategies, have been devalued, in part because of the shift to global economies, and in part because of an over-emphasis on labour costs as the major impediment to successful competition. We encourage the business community to look at other economies, notably in Europe, where it is generally agreed that sectoral strategies enhance industry's ability to compete. ${ }^{138}$

In its January 1998 Discussion Paper, the LRC Committee explicitly recognized a private sector representation gap, intensified by a shift towards low wage service sector employment, and stated that "we believe these issues are serious enough to warrant specific attention to the problem of sectoral bargaining and successorship." ${ }^{139}$ However, preferring non-statutory solutions, and noting that further research and discussion were necessary, the LRC Committee proposed establishing sectoral, joint labour-management industry advisory councils either under existing BC Code provisions for ministerial advisory councils or that would be non-statutory and voluntary. ${ }^{140}$

Final reports for both reviews were issued in late February 1998. ${ }^{141}$ Although the construction industry review recommendations were subsequently adopted, including a recommendation to reinstitute $\mathrm{BBB}$ in parts of that sector, none of the LRC Committee's recommendations were enacted. The LRC Committee emphasized non-statutory approaches and solutions, and repeatedly mentioned the polarized context of the review, inflamed by Bill 44 and the economic situation. Although the LRC Committee did not recommend legislating BBB "at this time," as Lanyon later noted, the Committee did not "reject [it] outright," pointing out that "clearly much more work needs to be done by academics, government, and the parties in looking at these types of regulatory schemes." 142

137 LRCRC, Managing change in labour relations - the final report, Part Four, B, Recommendation 7.

${ }^{138}$ LRCRC, Managing change in labour relations - the final report, Part 4.B.

139 LRCRC, Managing change in labour relations - a discussion paper, Section 2.2(b)(i).

140 LRCRC, Managing change in labour relations - a discussion paper, Executive Summary, Section 2.3(c).

${ }^{141}$ British Columbia, LRCRC, Report of the Construction Industry Review Panel: Looking to the future, taking construction labour relations into the 2Ist century (Victoria: Ministry of Labour, 1998); LRCRC, Managing change in labour relations - the final report.

${ }^{142}$ Notably, the public opinion research commissioned by the LRC Committee found that $54 \%$ of respondents supported, $20 \%$ opposed, and $24 \%$ were unsure about $\mathrm{BBB}$, defined in the question as "setting basic wages and benefits within an industry." It also found "overwhelming support" for successorship provisions. LRCRC, Managing change in labour relations - the final report, Recommendations 4, 7, Part 3.B; Lanyon, "British Columbia Labor Policy Proposals," 3I. 
However, in its final report the LRC Committee continued to recommend sectoral joint industry advisory councils, indicating that, with its recommendations "government moves away from its role of referee or regulator of these relationships to that of facilitator." 143 The LRC Committee also expressed the belief that "as other innovative strategies are put into place that involve joint labour-management collaboration at the industry or sectoral level, the issue of sectoral bargaining will cease to create the alarm and confusion that currently exists."144

Failure to achieve legislative change in support of BBB in BC in 1998 has largely been attributed to vigorous opposition from the small business community, although MacDonald suggests that the lack of consistency among union submissions contributed to this failure, as did the government's own lack of interest in BBB. ${ }^{145}$ Thereafter, the political situation in BC changed significantly. The Liberal party achieved an overwhelming majority in the 200I election and retained a majority government until the spring 2017 election. Worker-friendly labour law reform was not on this government's agenda, and BBB did not arise as an issue during this period.

\section{Revival of Interest in Broader-Based Bargaining}

\section{A. Ontario's Changing Workplaces Review}

BBB next arose in Ontario during the Changing Workplaces Review (CWR) of the OLRA and ESA which commenced in May 2015 and culminated in Bill I48, introduced in July 2017 and passed in late November $2017 .{ }^{146}$ To this point the Liberal government, in power since 2003 , had undertaken no review of, and had made only limited amendments to, the OLRA. ${ }^{147}$ However, the Liberals had committed to reviewing labour and employment legislation after their majority reelection in June 20I4, and some unions had been vigorously pressing for a combined review of the OLRA and ESA. ${ }^{148}$

In February 20I5 Minister of Labour Kevin Flynn appointed Special Advisors Justice John Murray, a former employer-side lawyer and judge, and Michael Mitchell, an arbitrator and former union-side labour lawyer, to lead the review. The CWR's mandate explicitly excluded consideration of construction labour relations, minimum wage, or matters being addressed by other independent review processes, such as pay equity, and broader public sector bargaining

143 LRCRC, Managing change in labour relations - the final report, Executive Summary, Recommendations 4 and 7.

${ }^{144}$ LRCRC, Managing change in labour relations - the final report, Part 4.B.

145 MacDonald, "The New Deal Model of Collective Bargaining and the Secondary Labour Market," 260-262.

146 Ontario, Bill I48, Fair Workplaces, Better Jobs Act, 20I7, S.O. 2017 c. 22.

147 See Bill I44, Labour Relations Statute Law Amendment Act, 2005, S.O. 2005, c. 15.

148 Kathleen Wynne, “Building Ontario Up - Speech from the Throne” (Toronto: Office of the Premier, 20I4), http://news.ontario.ca/opo/en/20I4/o7/building-ontario-up-speech-from-thethrone.html; Kathleen Wynne, "20I4 Mandate Letter: Labour” (Toronto, Office of the Premier, 20I4), http://www.ontario.ca/page/20I4-mandate-letter-labour; Fred Wilson, interview. 
structures. ${ }^{149}$

The context of this review was significantly different than Ontario's labour law reform exercise in the I990s. Not only was pay equity not an element in this review, but broader notions of labour rights under the Charter had new relevance. A series of Supreme Court of Canada cases issued since 200I and culminating in a trio of decisions issued in early 20I5, reversed decades of jurisprudence, finding that the Charter freedom of association encompassed protection of the process of collective bargaining, and recognizing strikes as both an essential element of the bargaining process and also protected by the Charter freedom of expression. ${ }^{150}$

Although the CWR was not plagued with the internal problems of the I990s OLRA review, deep animosity towards the Liberals led some unions, particularly in the public sector, to be reluctant to participate in the CWR. This was related to the Liberal government's contentious imposition of mandatory central bargaining in parts of the public sector. ${ }^{151}$

Proximity to the provincial election scheduled for June 2018 gave rise to skepticism about the government's commitment to labour law reform as more of a strategic political exercise. The upcoming election may also have influenced the NDP's approach to the CWR, which one labour researcher described as unsupportive, uninterested, cynical and giving the impression that the NDP "hop[ed] it would fail." In his view, the review would have been able to achieve more if the NDP had supported the process. ${ }^{152}$

At the outset of public consultations, the Special Advisors explicitly sought input on whether BBB was "required either generally or for certain industries." ${ }^{153}$ However, few submissions responded to this request, and fewer still offered specific input, instead often simply expressing general support for BBB. ${ }^{154}$ Notably, the OFL submission was silent on this issue. ${ }^{155}$ Instead,

149 Ontario, “Terms of Reference - Changing Workplaces Review” (Toronto: Ministry of Labour, 2017).

${ }^{150}$ Schedule B to the Canada Act 1982 (U.K.), I982, c. II, Ss. 2(b), (d); Mounted Police Association of Ontario v. Canada (Attorney General), 2015 SCC I; Meredith v. Canada (Attorney General), 2015 SCC 2; Saskatchewan Federation of Labour v. Saskatchewan, 2015 SCC 4.

151 These changes were most significant in the education sector. See for e.g. the successful Charter challenge of Bill II5, Putting Students First Act, 20I2, S.O. 20I2, c. II, which imposed centralized agreements in this sector: OPSEU v. Ontario, 20I6 ONSC 2197; and the subsequent Bill I22, School Boards Collective Bargaining Act, 20I4, S.O. 20I4, c. 5, which established mandatory centralized bargaining in this sector.

152 Fred Wilson, interview.

${ }^{153}$ Ontario, Changing Workplaces Review, “Guide to Consultations” (Toronto: Ministry of Labour, 20I5), Question I2.

154 See "Phase One: Public Submissions to the Changing Workplaces Review Interim Report," Industrial Relations and Human Resources (hereafter IRHR) digital collections, http://cirhr.library.utoronto.ca/digital-collection/changing-workplaces-review/publicsubmissions\#overlay-context.

155 See OFL, “Submission to Ontario’s ‘Changing Workplaces Review”” (Toronto: OFL, 20I5). 
during early stages of the CWR process most of the labour movement, including the OFL, had focused on incremental change to the OLRA, and a shortlist of priority issues. ${ }^{156}$ As explained by one labour researcher, the labour movement had made so few gains in labour legislation for so long in Ontario that there was no sense that significant advances could be made, so many unions concentrated on trying to "stop the decline ... and get a couple of little things." 157

Only the Steelworkers and Unifor submissions offered detailed responses on the BBB issue. ${ }^{158}$ The Steelworkers' National Office submission urged adoption of a slightly modified Baigent-Ready Model, and also sought a provision to consolidate existing bargaining units of a single employer. ${ }^{159}$ Unifor's submission contained extensive and detailed BBB submissions, and advocated strongly for a sectoral approach to both minimum standards regulation and collective bargaining. ${ }^{160}$ Unifor was convinced that the incremental change sought by much of the labour movement was insufficient, and had established a working group that devoted over six months to preparing the union's CWR submission. According to the coordinator of this working group, its attitude was: “let's make a seminal document. Let's go for broke here.”161

Two key ideas shaped Unifor's proposals. First, that it was necessary to "secure the floor" of workplace standards, in order to make organizing and bargaining possible in precarious sectors. As the BBB working group coordinator explained, if labour is always "filling in the collapsing floor" under precarious workers, it cannot move forward in organizing and improving conditions for these workers. The second formative concept arose from Unifor's foundational principles, which included the notion that labour's role was to speak for and represent all workers, whether or not they were unionized. However, this perspective had opponents both among other unions and within Unifor itself. Opponents contended that if workers wanted union protection and rights they should join unions, and that an all-worker approach meant that many workers would never unionize. $^{162}$

Unifor’s submission included several BBB proposals ranging from a proposal for singleemployer multi-site bargaining, to certification covering all franchisees in a geographic area of a common parent company, to a proposal for non-worksite based occupational representation, to an innovative BBB proposal founded in an amendment to the ESA. Unifor had not believed, until the CWR process was already well advanced, that OLRA amendments facilitating BBB might be

${ }^{156}$ Fred Wilson, interview.

${ }^{157}$ Fred Wilson, interview.

${ }^{158}$ Unifor developed a new model, addressed below. The Steelworkers pressed for adoption of the Baigent-Ready model. United Steelworkers (hereafter USW), "Submission by the United Steelworkers" (Toronto: USW, 2015).

159 This submission proposed there be no minimum threshold number of employees in a workplace for the model to apply. USW, "Submission by the United Steelworkers," 3I-33.

${ }^{160}$ Unifor, “Building Balance, Fairness, and Opportunity in Ontario’s Labour Market” (Toronto: Unifor, 20I5), I04-I30.

${ }^{161}$ Fred Wilson, interview.

${ }^{162}$ Fred Wilson, interview. 
politically possible, so the union's most ambitious proposal relied on modifications to the ESA rather than the OLRA. ${ }^{163}$

The CWR Interim Report, issued in late July 20I6, set out nine options for potential BBB amendments to the OLRA. In addition to maintaining the status quo, options included proposals for: multi-employer, multi-location certifications; extension of certifications or agreements; and, BBB models for specific industries or sectors. Some options involved detailed proposals, others were explicitly based on the Baigent-Ready Model, the Québec Decrees system, or the ISA (see Table I, below). ${ }^{164}$ Option 5, which had been developed by the Special Advisors, was set out in greatest detail. This new proposal, modified the Baigent-Ready model by providing that multiemployer, multi-location certification, voting, and negotiations would occur on a sector-wide basis, and an applicant union would be required to demonstrate to the labour board its commitment to sectoral representation, potentially including demonstration of a resource commitment sufficient to confirm the union's willingness to attempt to organize the entire sector.

${ }^{163}$ Fred Wilson, interview

${ }^{164}$ Ontario, Ministry of Labour, Changing Workplaces Review - Special Advisors' Interim Report (Toronto: Ministry of Labour, 20I6), II3-II9, I22-I26. 
Table I Changing Workplaces Review, Interim Report, Broader Based Bargaining Options

\begin{tabular}{|l|l|}
\hline Option & Summary \\
\hline I & Maintain status quo. \\
\hline 2 & $\begin{array}{l}\text { Model providing for extension of negotiated provisions across a sector. Reflects the } \\
\text { Québec decrees system, ISA, and Unifor's proposal. }\end{array}$ \\
\hline 3 & $\begin{array}{l}\text { Accretion of single location certifications of single franchisor/franchisee units with } \\
\text { the same parent company leading to multi-location bargaining. }\end{array}$ \\
\hline 5 & $\begin{array}{l}\text { Multi-employer, multi-location certification and bargaining, arising from single- } \\
\text { employer, location by location certifications, and based on the Baigent-Ready Model. }\end{array}$ \\
\hline 6 & $\begin{array}{l}\text { A new proposal for multi-employer, multi-location certification and bargaining, } \\
\text { involving sector-wide certification. } \\
\text { A new proposal based on the accretion approach to BBB in the construction industry, } \\
\text { resulting unions being compelled to bargain sector wide agreements. Aimed at } \\
\text { industries with existing, but fragmented, union representation and intended to support } \\
\text { employer interests in BBB structures and to avoid union "whipsawing” and } \\
\text { "leapfrogging”. }\end{array}$ \\
\hline 7 & $\begin{array}{l}\text { A proposal, with no details provided, to develop a model aimed at vulnerable workers } \\
\text { in precarious employment, such as home care workers, or (if exclusions from the } \\
\text { OLRA were removed) agricultural, domestic or horticultural workers, where the } \\
\text { Wagner model is ineffective. }\end{array}$ \\
\hline $\begin{array}{l}\text { A model based on the Status of the Artist Act approach, to apply to freelance workers } \\
\text { and dependent contractors. No specifics were provided. }\end{array}$ \\
$\begin{array}{l}\text { Create provisions of the OLRA applying to the media industry, artists and performers. } \\
\text { No specific were provided. }\end{array}$ \\
\hline 5
\end{tabular}

Source: Interim report. Ontario, Ministry of Labour, Changing Workplaces Review Special Advisors' Interim Report (Toronto: Ministry of Labour, 20I6), I22-I26.

The Interim Report sought input from the community on these options and a second phase of written submissions and stakeholder meetings followed. Unifor, at least, was surprised by the Interim Report's clear willingness to entertain introducing BBB within the OLRA. ${ }^{165}$ Although the Interim Report elicited more union input about BBB than had been received in the first phase of submissions, relatively few unions engaged substantially with the issue. Most unions, and the OFL,

${ }^{165}$ Fred Wilson, interview. 
simply indicated support for several of the options in their phase 2 submissions. ${ }^{166}$

Although it appeared that the Special Advisors were most seriously contemplating recommending option 5, the proposal that they had developed, several unions raised concerns about that approach, regarding option 4, which closely resembled the Baigent-Ready Model, as more incremental, less disruptive, and more practical. Concerns included that option 5 would have sparked inter-union rivalries as it would result in either a single union or a council of unions representing a sector; that the sector-wide certification element would require a state of readiness to immediately deal with an entire sector that few unions would be able to muster; that it would produce a "large cultural change for many affected employers, and for workers"; and, that sectorwide certification would be a substantial barrier to accessing sectoral certification. ${ }^{167}$

Notably, several unions expressed reservations about BBB, in general, concerned about protection of existing union representation rights. They urged that any introduction of BBB be limited to sectors without significant existing union representation, and that new BBB structures not displace established bargaining arrangements. ${ }^{168}$ Some unions also objected to sectoral certification models that might prevent unions from organizing in particular sectors. ${ }^{169}$ One of the province's largest public sector unions, OPSEU, emphasized that BBB should be voluntary for unions and not forced upon unions as it had been in the education sector. ${ }^{170}$

The few employer submissions that addressed the issue opposed BBB and advocated for status quo. ${ }^{171}$ Opposition centred on assertions that such models are inappropriate for the private sector, that it "takes away the creativity, the competitive advantage that companies seek to

166 See "Phase Two: Public Submissions to the Changing Workplaces Review Interim Report," IRHR digital collections, http://cirhr.library.utoronto.ca/digital-collection/changing-workplacesreview/public-submissions-phase-two. As an exception, the Ontario Nurses’ Association made an additional submission calling for BBB tailored to the health care sector: Ontario Nurses' Association (hereafter ONA), "Supplemental Submissions to the Ontario Changing Workplaces Review” (Toronto: ONA, 20I6).

167 Fred Wilson, interview; Unifor, "Response to the Interim Report of the Ontario Changing Workplaces Review" (Toronto: Unifor, 20I6), 30; ONA, "Response to the Ontario Changing Workplaces Review Interim Report” (Toronto: ONA, 20I6), 7.

${ }^{168}$ See Society of Energy Professionals (hereafter SEP), "Submission for the Changing Workplaces Review - Interim Report” (Toronto: SEP, 20I6), I2; Fred Hahn, "Canadian Union of Public Employees (CUPE): Changing Workplaces Review - Response to the Interim Report” (Toronto: CUPE, 20I6), I6.

169 Ontario Public Service Employees Union (hereafter OPSEU), “Supporting positive change for working people in Ontario" (Toronto: OPSEU, 20I6), I5; Fred Hahn, "CUPE - Response to the Interim Report," I7.

${ }^{170}$ OPSEU, “Supporting positive change for working people in Ontario,” I5.

171 See e.g. ACS Coalition, “Submissions: Changing Workplaces Review Interim Report” (Toronto: ACS, 20I6); Maple Leaf Foods, "Changing Workplace Review - Additional Submission” (Mississauga: Maple Leaf Foods, 20I6); Bob Doyle et al., "Letter regarding Changing Workplaces Review” (Belleville, Madoc, and Brighton: McDonalds, 20I6). 
prosper," 172 and that it would conflict with different wage structures and hierarchies at different workplaces. ${ }^{173}$ Several employer associations expressed concern about the disadvantage smaller employers would face, even within a single franchise system, in a bargaining council; ${ }^{174}$ concern that smaller and medium size businesses would lack sufficient resources to bargain with larger unions; ${ }^{175}$ and, concern that larger firms would be advantaged over small and medium firms as they would be more able to manage the costs of a BBB bargaining structure, which may lead to smaller businesses closing, thereby reducing "employee choice” of types of workplaces. ${ }^{176}$

Public sector employer associations focused on the potential for BBB to change the balance of labour relations power, thus increasing the risk of strikes. ${ }^{177}$ Notably, while the Ontario Hospital Association opposed the Interim Report options, it recommended mandatory, statutory union councils for centralized bargaining in the hospital sector as a means of rationalizing bargaining structures. ${ }^{178}$

In late May 20I7, the CWR Final Report was released. It dismissed extension models, including the extension model option based on Unifor's proposal (Table I, option 2), as being “out of keeping with Ontario's history and culture" and concluded that determination of some workplace terms by the unionized sector, to be imposed on the non-union sector, was neither practical nor likely to be accepted, in the absence of a democratic means for employees to consent to these terms. ${ }^{179}$

The Final Report also rejected "multi-employer bargaining models" based on the BaigentReady Model (Table I, options 4 and 5). While noting that these models are "creative and worthy of further exploration" the Special Advisors concluded that it was it was not clear that this approach would work in sectors with little history of collective bargaining. It further noted that "no jurisdiction that we are aware of has imposed a mandatory multi-employer collective bargaining regime on employers in a sector without any history of collective bargaining in that sector. Such

172 Maple Leaf Foods, “Changing Workplace Review - Additional Submission,” 2.

${ }^{173}$ Bob Doyle et al., "Letter regarding Changing Workplaces Review," 5.

${ }^{174}$ Canadian Franchise Association (hereafter CFA), “The Modern Workforce: The Contribution \& Future Opportunity of Franchising in Ontario” (Toronto: CFA, 20I6), I4-I5; Restaurants Canada, "Response to Changing Workplaces Review Interim Report" (Toronto: Restaurants Canada, 20I6), 7-8; Keep Ontario Working with Philip Cross, "Reform that Works: A Call for Evidence-Based Workplace Law Modernization in Ontario” (Toronto: Keep Ontario Working, 20I6), 35.

${ }^{175}$ Restaurants Canada, "Response to Changing Workplaces Review Interim Report,” 7-8.

176 Restaurants Canada, "Response to Changing Workplaces Review Interim Report," 7-8; Tourism Industry Association of Ontario (hereafter TIAO), "Submission to The Changing Workplaces Review” (Toronto: TIAO, 20I6), 2.

177 Council of Ontario Universities (hereafter COU), "Submission on the Changing Workplaces Review” (Toronto: COU, 20I6), 5.

${ }^{178}$ Ontario Hospital Association (hereafter OHA), "Response to the Changing Workplaces Review Interim Report” (Toronto: OHA, 20I6), 9.

${ }^{179}$ C. Michael Mitchell and John C. Murray, Final Report, 354. 
an option, therefore, calls for a considerable degree of caution and careful assessment.” ${ }^{180}$ One concern was that, in multi-employer bargaining structures, larger businesses might collude to increase labour costs which might remove smaller businesses from the market. A further concern was whether, under these models, unions would be able to gain sufficient bargaining power against a heterogeneous group of employers. 181

The Report did not specifically address option 6, the construction accreditation model. The Special Advisors recommended that the government conduct inquiries and consultations regarding options 7, 8, and 9 (Table I), which had suggested new models for industries with vulnerable and precarious workers, in which the Wagner Model is ineffective; for freelancers and dependent contractors; and, for the media industry. ${ }^{182}$

The Final Report did recommend amending the OLRA to adopt a BBB model which would be applicable only to franchisees of a single common franchisor, and which did not require including the franchisor in the bargaining structure. This recommendation appeared to be based on option $3 .{ }^{183}$

The most innovative BBB recommendation that appeared in the Final Report, reflecting Unifor's key phase I proposal and reminiscent of Ontario's former Industrial Standards Act, had not appeared among the Interim Report options. The Special Advisors recommended amending the ESA to establish "sector committees" to provide for sectoral regulation of workplace standards. The Special Advisors explained that this approach was more feasible and "a better more inclusive way to accomplish some improvement in outcomes for employees in smaller non-unionized workplaces" than an extension model, as it would allow for direct employee and employer input, with government regulation. ${ }^{184}$

Bill I48, the Fair Workplaces, Better Jobs Act, 20I7, was introduced and passed first reading on June Ist, 20I7, a week after the Final Report was released. It contained no BBB provisions among the proposed amendments to the LRA or ESA, but did include two provisions giving the OLRB limited authority to consolidate bargaining units. ${ }^{185}$

The NDP's reaction to Bill I48 has been described as "muted" and the party offered no substantial response to the Bill until mid-August, at which time NDP Leader Andrea Horwath announced proposed amendments to the Bill. ${ }^{186}$ These amendments were not tabled until

\section{${ }^{180}$ C. Michael Mitchell and John C. Murray, Final Report, 355-356.}

181 The Report also noted there was "virtually no support for Option 5 in the submissions." C. Michael Mitchell and John C. Murray, Final Report, 355-356.

182 C. Michael Mitchell and John C. Murray, Final Report, 364-366.

${ }^{183}$ C. Michael Mitchell and John C. Murray, Final Report, 360-362. The Final Report also included recommendations to expand the scope for consolidation and amendment of bargaining units, distinct from the issue of BBB. C. Michael Mitchell and John C. Murray, Final Report, 35I-352.

184 C. Michael Mitchell and John C. Murray, Final Report, 354.

185 Bill I48, first reading, Fair Workplaces, Better Jobs Act, 20I7, S.O. 20I7, c.22, Ss. I5.I and I5.2.

${ }^{186}$ Chris Grawey, Labour Law Review Processes I990 to 2017 (Canadian Foundation for Labour Rights Ontario, 20I8), 35-36, http://labourrights.ca/research-publications/ontario-labour-law- 
November 20I7, and focused on the ESA, with limited OLRA proposals, and no mention of BBB. ${ }^{187}$

Bill I48 was significantly amended following two rounds of public consultations held in summer and fall 20I7, and during Second Reading. Consequently, one of the bargaining unit consolidation provisions was dropped and the second was substantially narrowed. Bill I48 received Royal Assent on 27 November 20I7, and the majority of amendments came into force on I January 20I8. ${ }^{188}$

Following the June 2018 election of the Progressive Conservative Party of Ontario, Bill 47 proposed repealing or replacing most of the Bill I 48 amendments. Interestingly, Bill 47 provided for greater scope for consolidation of bargaining units than did Bill I48, by proposing to repeal the Bill I48 consolidation provisions and replace them with OLRB power to consolidate units certified to the same or different unions of the same employer where the existing units are "no longer appropriate for collective bargaining." 189 This would essentially adopt the Canada Labour Code consolidation provisions, which Ontario unions had objected to during the CWR review, as a threat to established representation rights. The OFL and other unions objected to these consolidation provisions, contending that it would cause instability due to conflict between unions, and arguing that loss of workers' ability to select their bargaining agent undermines their freedom of association rights. ${ }^{190}$

\section{B. Alberta Labour Code Reviews}

In July 2002, Alberta Human Resources and Employment Minister Clint Dunford appointed a committee composed of three Members of the Legislative Assembly, to assess whether review of the province's Labour Relations Code (Alberta Code) should be undertaken. ${ }^{191}$ Following consultations during the summer of 2002, the MLA Committee submitted its final report

review-processes-I990-20I7; Ontario NDP, “NDP Leader Horwath pushes for major labour reforms” (Media release, Io August 20I7), http://www.ontariondp.ca/news/ndp-leader-horwathpushes-major-labour-reforms-ontario-ndp.

187 Ontario NDP, “Horwath determined to improve working conditions for all” (Media release, 8 November 20I7), http://www.ontariondp.ca/news/horwath-determined-improve-workingconditions-all.

188 Ontario, Fair Workplaces, Better Jobs Act, 20I7, S.O. 20I7, c.22. These amendments permitted consolidation of newly certified units with existing units where both the bargaining agent and the employer were the same; and, consolidation of existing units with different bargaining agents but the same employer, where all parties consented.

189 Ontario, Bill 47, Making Ontario Open for Business Act, 20I8, S.O. 20I8, Schedule 2, s. 6.I.

190 OFL, "Submission to the Standing Committee on Finance and Economic Affairs - Do the Right Thing: Stand up for Workers” (Toronto: OFL, 20I8),I2, I3, http://ofl.ca/wp-content/uploads/20I8II-I5-SM-Bill-47.pdf; Unifor, "Submission to the Standing Committee on Finance and Economic Affairs - Bill 47, Making Ontario Open for Business Act” (Toronto: Unifor, 20I8), 7, http://www.unifor.org/sites/default/files/brief-statements/uniforbill47submissionfinal.pdf

${ }^{191}$ Alberta, Labour Relations Code, R.S.A. 2000, c L-I. 
to the Minister in late November of that year. The government accepted the final report's recommendations that no general review of the Alberta Code be undertaken, but that specific provisions merited review. ${ }^{192} \mathrm{BBB}$ was not addressed in this review.

Neither BBB nor labour law reform returned to the agenda in this province for another fifteen years, after the Progressive Conservatives, in power since I97I, were displaced by an NDP government. In March 20I7, Alberta's recently-elected government announced a review of the Alberta Code and the province's Employment Standards Code. ${ }^{193}$ This was followed by a brief, five-week consultation period, resulting in Bill I7 introduced in late May and passed early the next month. ${ }^{194}$ Andrew Sims, Q.C., arbitrator, mediator, and former chair of the Alberta Labour Relations Board, provided technical advice on the Alberta Code review. Although Sims' mandate letter identified ten specific areas of the Alberta Code to be reviewed, these did not include BBB, and the government made it clear that it would not entertain significant innovations in these areas. ${ }^{195}$ As Sims told the press "this is not a cutting-edge, lead-the-country reform .... It is in most respects a bring-the-best-experiences-from-elsewhere to Alberta.”196

The Alberta Federation of Labour's submission included a general statement supporting sectoral bargaining, but made no specific proposal, and simply requested that the government "add the opportunity for unions in a recognizable sector of the economy to apply to the Board to bargain sectorally and/or in groups.”"197

Not surprisingly, particularly given the significant amendments necessary for Alberta's workplace legislation to catch up to the norm elsewhere in the country, BBB was not a significant issue in this review, and the resulting Alberta Code amendments did not include any BBB provisions.

192 Alberta, Government MLA Committee, Final Report: Government MLA Committee Considering a Review of the Labour Relations Code (Edmonton: Government of Alberta, November 2002); Government of Alberta, News Release, "Labour Relations Code is working well," 8 July 2003, http://www.gov.ab.ca/acn/200307/I4747.html.

193 Alberta, Labour Relations Code; Alberta, Employment Standards Code, R.S.A. 2000, c. E-9.

${ }^{194}$ Alberta, The Fair and Family-friendly Workplaces Act, S.A. 20I7, c. 9.

195 Christina Gray to Andrew Sims, I3 March 20I7, Alberta Minister of Labour, http://www.alberta.ca/assets/documents/labour-relations-code-review-mandate-letter.pdfh;

Cameron Dykstra, interview by author, I May 2018.

196 Michelle Bellefontaine, "Labour, employment code overhaul brings Alberta law into 'mainstream,"' CBC News, 24 May 20I7, http://www.cbc.ca/news/canada/edmonton/labouremployment-code-overhaul-brings-alberta-law-into-mainstream-I.4I30059.

197 Cameron Dykstra, interview; Alberta Federation of Labour (hereafter AFL), "Submission to the Labour Relations Code Review” (Edmonton: AFL, 20I7), 34. However, an Appendix to this submission referred to several earlier BBB proposals, arguing that BBB may be an appropriate policy response to precarious work, and that such bargaining structures have "ample precedent." 


\section{Revisiting British Columbia's Labour Relations Code}

During the sixteen years of Liberal rule in the province, which had begun in 200I, the labour movement focused on simply "trying to defend the store" and "were just trying to hang on [while] sustaining some pretty heavy losses in terms of labour laws" and "most of the focus was simply on defending and trying to get back to some basic sort of ideas about bargaining and trying to defend some semblance of collective bargaining." ${ }^{198}$ Although the Liberal government undertook two BC Code reviews during its tenure, in 2003 and 2007, neither BBB nor the Baigent-Ready Model in particular appear to have been either raised or addressed in either review. ${ }^{199}$

A historically close May 2017 provincial election produced no majority, and, after the NDP's non-confidence motion passed in late June, the party was invited by the LieutenantGovernor to form a minority government. This minority government depends upon a NDP-BC Green Party "Confidence and Supply" agreement to retain power. ${ }^{200}$

In early February 20I8, the NDP government announced a review of the $B C$ Code would be undertaken by a tripartite panel of special advisors: arbitrator Mike Fleming, employer-side counsel Barry Dong, and union-side counsel Sandra Banister (the "Review Panel”). Although the Review Panel was given a broad mandate, it was also clear that the Minister of Labour was not prepared to undertake a review on the scale of the recent Ontario CWR. The government appeared to be prepared to act on some longstanding concerns, and there was a sense of urgency to amending the legislation. ${ }^{201}$ The process included seeking written submissions and holding regional meetings in the spring, with a final report to be submitted to the government in August 2018.

BBB was addressed by both labour and employers in this review, although the Review Panel noted that they "conflate the concepts of multi-employer certification and multi-employer bargaining." 202 Several union submissions dealt with BBB, with many emphasising that, unlike Ontario, BC has a long and established history of BBB structures in both its public and private

198 John Weir, interview.

199 British Columbia, LRCRC, Report of the B.C. Labour Relations Code Review Committee Regarding the role of Members of the Labour Relations Board (Victoria: Ministry of Labour, 2007); British Columbia, LRCRC, Report of the B.C. Labour Relations Code Review Committee to the Minister of Skills Development and Labour (Victoria: Ministry of Labour, 2003).

${ }^{200}$ British Columbia, "20I7 Confidence and Supply Agreement between the BC Green Caucus and the BC New Democrat Caucus," 30 May 20I7, http://www2.gov.bc.ca/assets/gov/britishcolumbians-our-governments/organizational-structure/central-government-agencies/governmentcommunications-public-engagement/confidence-and-supply-agreement-secretariat/casa_may $30 \quad 2017 . p d f$.

${ }^{201}$ Anita Zaenker, interview by author.

202 British Columbia, Labour Relations Code Review Panel, A Report to the Honourable Harry Bains Minister of Labour / Recommendations for Amendments to the Labour Relations Code (Victoria, BC: Ministry of Labour, 20I8), I7. 
sectors. ${ }^{203}$ However, and although Review Panel members had asked the labour community about $\mathrm{BBB},{ }^{204}$ most submissions simply included a general call for multi-employer sectoral certification, but without a specific proposal or any details, with several specifying that this be for "traditionally difficult to organize sectors," ${ }^{205}$ calling for a committee of special advisors to be struck to examine this issue and to make recommendations, ${ }^{206}$ or for BBB for franchisees. ${ }^{207}$

The first specific BBB proposal was offered by United Food and Commercial Workers, Local I5I8: a proposal for BBB in the franchise context, based on one of the Ontario CWR Final Report Recommendations. ${ }^{208}$ Two other organizations, the Migrant Workers' Centre and the Vancouver Committee for Domestic Workers and Caregivers Rights also offered specific proposals, and these were influenced by existing broader-based, centralized bargaining structures in BC's public sector, and a BBB proposal developed in the early I990s by a domestic workers' organization in Ontario. ${ }^{209}$ The first proposed a two-tier BBB representation and bargaining structure to apply to caregivers in the private sector, modelled on the statutory structure existing in BC's publicly funded health and community social services sector. The second contemplated mandatory province-wide bargaining (including sectoral certification and bargaining), employing the central workers' registry existing under the BC ESA, and including establishment of a Tri-partite

${ }^{203}$ Unifor, "Make it Fair: Restoring Balance, Fairness and Opportunity in B.C.’s Labour Market” (Vancouver: Unifor, 20I8), 5; Health Sciences Association (hereafter HSA), "Submission to the Labour Relations Code Review Panel” (New Westminster: HSA, 20I8), I; Migrant Workers Centre (hereafter MWC), "Submission to the Section 3 Panel Reviewing the British Columbia Labour Relations Code" (Vancouver: MWC, 20I8), 6.

${ }^{204}$ Anita Zaenker, interview by author.

205 Canadian Union of Public Employees British Columbia Division (hereafter CUPE BC), "Submission to the Section 3 Panel Regarding British Columbia Labour Relations Code Reform" (Burnaby, BC: CUPE BC, 20I8), 6; British Columbia Teachers' Federation (hereafter BCTF), "Submission to the Labour Relations Code Review Panel" (Vancouver: BCTF, 20I8), 6; BC Government and Service Employees' Union (hereafter BCGEU), "Submission to the Labour Relations Code Review Panel” (Burnaby, BC: BCGEU, 20I8), 3, 7.

${ }^{206}$ Hospital Employees' Union (hereafter HEU), 'Submission to the Special Advisers to the Minister of Labour” (Burnaby, BC: HEU, 20I8), II.

${ }^{207}$ HSA, "Submission to the Labour Relations Code Review Panel," 4-5; Retail Action Network (hereafter RAN), "Submission to the Labour Relations Code Review Panel” (Victoria, BC: RAN, 20I8), 4; Unifor, "Make it Fair: Restoring Balance, Fairness and Opportunity in B.C.'s Labour Market," 6.

${ }^{208}$ C. Michael Mitchell and John C. Murray, Final Report, 360-36r; United Food and Commercial Workers (hereafter UFCW), "Submission to the Labour Relations Code Review Panel" (New Westminster, BC: UFCW, 20I8), 8-9.

${ }^{209}$ Intercede, Meeting the Needs of Vulnerable Workers; MWC, "Submission to the Section 3 Panel Reviewing the British Columbia Labour Relations Code," 7-I3; Vancouver Committee for Domestic Workers and Caregivers Rights (hereafter CDWCR), "Submission to BC Labour Relations Code Review Advisors” (Vancouver: CDWCR, 20I8), 2-6. 
Standards Committee under the $B C$ Code, to negotiate, set, and enforce labour and employment standards for the sector. Such standards would be subject to government approval, before being enacted as regulations.

Notably, the submissions of neither the BC Fed, nor several other key organizations and unions, made any reference to BBB. ${ }^{210}$ However, the BC Fed had chosen to include only proposals which were unanimously supported by its affiliates. The BC Fed asked affiliates to make their own submissions on other issues. ${ }^{211}$

Also of note was that BBB was "raised more consistently and vocally by employers than unions” in the consultation process, including in a joint submission by thirteen private sector employer organizations and employers, a group regarded as the dominant employer voice in this process. ${ }^{212}$ Employer submissions characterized BBB as a threat to businesses' autonomy and selfdetermination that would disregard the needs and circumstances of individual businesses, and would deprive newly certified employers of control over terms and conditions of their own business, potentially imposing unaffordable terms and conditions on these employers, and violating the $B C$ Code principle that parties have a direct voice in terms and conditions of employment. ${ }^{213}$ Several employers in the technology industry emphasized the heterogeneity of enterprises in that sector, and argued that common interests among employers is a pre-condition to non-disruptive BBB structures. ${ }^{214}$ Other employer submissions also characterized statutory BBB as "a step back in time," 215 emphasizing the trend towards decentralized bargaining in other English-speaking jurisdictions, ${ }^{216}$ and arguing that although BBB may be appropriate in some

210 BC Federation of Labour (hereafter BC Fed), "Submission to the Labour Relations Code Review Committee” (Vancouver: BC Fed, 20I8). And for example, see Vancouver \& District Labour Council (hereafter V\&DLC), "V\&DLC Submission” (Vancouver: V\&DLC, 20I8); Canadian Association of Labour Lawyers (hereafter CALL), "Submission to the Labour Relations Code Review Panel" (Ottawa: CALL, 20I8); United Steelworkers, "Submissions to the Review Panel under Section 3 of the British Columbia Labour Relations Code” (Burnaby, BC: United Steelworkers, 20I8). Notably, Unifor did not offer the detailed submissions it had provided in the Ontario CWR process. Nor did it participate in the BC Fed coordinated process, as this occurred after its withdrawal from the CLC in January 20I8. Unifor, "Make it Fair: Restoring Balance, Fairness and Opportunity in B.C.'s Labour Market.”

${ }^{211}$ Anita Zaenker, interview.

212 Union Representative \#I, interview by author; Retail Council of Canada (hereafter RCC), "Submission on the BC labour Relations Code Review" (Vancouver: RCC, 20I8), 6-7.

213 Retail Council of Canada (hereafter RCC), "Submission on the BC labour Relations Code Review” (Vancouver: RCC, 20I8), 6-7; Business Council of British Columbia (hereafter BCBC), "Submission to the Labour Relations Code Review Panel” (Vancouver: BCBC, 20I8), 6-7.

${ }^{214}$ DigiBC, “Submission to the Labour Relations Code Review Panel” (Vancouver: DigiBC, 20I8), 7-8.

${ }^{215}$ RCC, "Submission on the BC labour Relations Code Review," 7.

${ }^{216}$ BCBC, "Submission to the Labour Relations Code Review Panel," 7. 
industries where there exists an established history of collective bargaining, it is not appropriate for industries lacking this history. ${ }^{217}$ In particular, franchise sector representatives contended that sectoral representation and bargaining would threaten the viability of the franchise model and, therefore, investment in the province. ${ }^{218}$

The minority status of the NDP government and significant differences in priorities and perspectives between the NDP and Greens provides a complicated context for labour law reform in BC. The Green party leader Andrew Weaver has adamantly opposed a key NDP labour law reform goal, reinstitution of the card-based certification process, and was quoted as saying "I will never support legislation that will eliminate the secret ballot .... It's simply not going to happen." ${ }^{219}$ More recently Weaver has stated that the BC Greens will consider proposed BC Code amendments on their merits. ${ }^{220}$ The Confidence and Supply agreement offers little assurance of Green support for NDP labour law reform efforts. It explicitly provides that the NDP will consult with the Green party and "BC Green support for policy and legislation which does not relate to confidence or supply is not subject to this agreement and will be decided on an issue by issue basis." 221

The Review Panel's final report, submitted to the Minister on 3r August 20I8, concluded that it had not received sufficient information or analysis to make specific recommendations about either sectoral certification or bargaining. It did, however, suggest that sectoral certification be studied by a single-issue commission, and recommended that sectoral, multi-employer bargaining be considered by an industrial inquiry commission or industry councils pursuant to section 80 of the $B C$ Code. ${ }^{222}$ The subsequent amendments to the BC Code, passed in May 2019, did not address $\mathrm{BBB}$, although provided for stronger successorship rights upon contract retendering in specified sectors. ${ }^{223}$

${ }^{217}$ DigiBC, "Submission to the Labour Relations Code Review Panel," 7.

${ }^{218}$ Labour Relations Code Review Panel, A Report to the Honourable Harry Bains Minister of Labour / Recommendations for Amendments to the Labour Relations Code, I7.

${ }^{219}$ Rob Shaw, "B.C. Greens kill NDP's proposed change on unionized secret ballots," Vancouver Sun, 2I June 20I7, http://vancouversun.com/news/politics/b-c-greens-kill-ndps-proposed-changeto-unionized-secret-ballots.

${ }^{220}$ Ian Bailey, “B.C. panel holds public hearing amid review of province's labour code," Globe \& Mail, 20 March 20I8, www.theglobeandmail.com/canada/british-columbia/article-bc-panel-holdspublic-hearing-amid-review-of-provinces-labour-code/.

${ }^{221}$ British Columbia, 2017 Confidence and Supply Agreement, s.I.

${ }^{222}$ Labour Relations Code Review Panel, A Report to the Honourable Harry Bains Minister of Labour / Recommendations for Amendments to the Labour Relations Code, 17, 26, Recommendation

I9, http://engage.gov.bc.ca/app/uploads/sites/I332/20I8/Io/Labour-Relations-Code-Review-PanelReport.pdf.

${ }^{223}$ Labour Relations Code Amendment Act, 2019, 2019 S.B.C. c. 28. 


\section{Conclusion}

Over the last three decades, broader-based and sectoral bargaining proposals have arisen in numerous private sector collective bargaining law reform episodes across the country. In each case BBB failed to garner widespread support and frequently met with opposition from the labour movement. Proposals were also received with varying degrees of employer opposition and government disinterest. In every instance BBB proposals failed to be incorporated into subsequent legislative amendments.

Given that the structural challenges of enterprise-based representation and bargaining, intensified by the continuing shift towards smaller workplaces and non-standard work arrangements; growing inequality; and, more effective employer resistance to unions are among the key difficulties faced by unions and workers, it is surprising that the labour movement has not embraced and prioritized BBB reforms. This is particularly perplexing in the face of long-standing evidence that centralized and coordinated bargaining structures are associated with better workplace and labour market outcomes for workers and unions.

The present study sought, through interviews of union representatives, researchers and policy advisors involved in labour law reform episodes within the period under study, to reach a better understanding of the labour movement's lack of strong engagement with this issue, given that unions and their members appeared to have the most to gain from BBB reforms.

Earlier assessments of labour law reform in Ontario and British Columbia in the I990s have explained these failures as arising from strong employer resistance to the proposals; widespread lack of knowledge or understanding of the concept (especially among the labour movement), or by characterizing BBB as a concept too foreign to be introduced to the Wagner Model of collective bargaining. ${ }^{224}$ However, these explanations are not adequate to explain the continued failure of $\mathrm{BBB}$ proposals in recent decades, and the present study offers evidence for a different understanding of this recurring phenomenon.

First, while vehement employer opposition may have contributed to failure of BBB proposals in the I990s, strong employer opposition to BBB was not been a prominent feature of recent collective bargaining law reform experiences. Therefore, additional explanations must be considered.

Second, earlier studies suggest that the labour movement's lack of support for, and even opposition to, BBB was rooted in a lack of understanding of the notion. However, recent labour law reform episodes demonstrate that, unlike what may have been the case in the I990s, there is now substantial awareness and understanding of BBB within the labour movement, and that unions have been willing to inform themselves about the concept, including discussing and actively seeking to understand other unions' differing views. ${ }^{225}$ Similarly, lack of understanding of the growing crisis in unionization is not a satisfactory explanation. While there was limited recognition

\footnotetext{
${ }^{224}$ See comprehensive case studies by Eaton, "Labour law reform for the new workplace: Bill 40 and beyond"; Diane MacDonald, "Sectoral Certification: A Case Study of British Columbia; Diane MacDonald, "The New Deal Model of Collective Bargaining and the Secondary Labour Market"; Labour Researcher, interview by author; Ken Georgetti, interview by author.

${ }^{225}$ Union Representative \#2, interviewed by author.
} 
within the labour movement in the I990s of the necessity for new modes of organizing and bargaining, including broader-based approaches, there can be no doubt that today's labour movement is aware of the critical difficulties facing unions.

In contrast with earlier research, the present study offers a different explanation for some unions' lack of support for, or opposition to, BBB. It finds that union resistance arises from three sources. First, concern that BBB threatens some unions' ability to preserve existing representation rights. Second, some unions' resistance to the prospect of being required to participate in a council of unions in which their own bargaining power may be diluted. Third, anticipation of jurisdictional conflicts among unions resulting from new, broader-based representation and bargaining structures. Additionally, it became evident in the course of this study that the consensus approach taken by peak labour organizations to decide which labour law reform issues to advocate for explains the silence and lack of advocacy for BBB by many labour federations. These sources of resistance explain unions' lack of support for BBB in both early and contemporary labour law reform efforts, and may be the most significant barriers to adoption of BBB in the future.

Finally, past studies appear to attribute government's disinterest in BBB reforms to lack of knowledge of the concept. This is difficult to reconcile with the active exploration of the issue by some of those tasked with making labour law reform recommendations, such as the urgent invitations by members of the $1992 \mathrm{BC}$ Sub-committee and the 2015 Ontario CWR to the labour relations community to provide BBB submissions and input, which met with limited response. A more compelling explanation is that governments have been unwilling to undertake novel reform which is likely to meet with employer opposition, and which has little union support. Given the highly politicized nature of labour law reform, and, therefore, the political cost of innovative and untried changes, it is not surprising that governments opted to forgo such a contentious route, despite the socio-economic benefits it may produce, particularly for workers.

Looking ahead to a future likely to continue to be characterized by ongoing, if not accelerating, stagnation or decline in union density, growth of smaller workplaces, waning of traditional employment relationships, and increasing inequality, the potentially stabilizing effects of BBB may be of more importance to workers than ever while it may also appear to be a greater threat to the survival of vulnerable unions. As a result, the labour movement and its peak organizations may have to directly confront the dilemma of whether to try to protect certain individual unions' existing rights or whether to try to protect the broader labour movement, and workers, through pursuing BBB.

\section{Acknowledgements}

I am grateful to Harry Arthurs, Timothy Bartkiw, Matthew Dimick, Stan Lanyon, Chris Schenk, and three anonymous reviewers for helpful comments and suggestions, and to Nora Parker for her able research assistance. I also acknowledge the Osgoode Research Fellowship which allowed me time to conduct this research. 